\title{
Total Synthesis of the Non-adjacently Linked Bis-tetrahydrofuran Acetogenin Bullatanocin (Squamostatin C)
}

\author{
Lei Zhu and David R. Mootoo \\ Department of Chemistry, Hunter College/CUNY, 695 Park Avenue, New York, NY \\ 10021 \\ dmootoo@hunter.cuny.edu
}

\section{Supporting Information}

Experimental procedures and physical data for new compounds

S01-S19

Tabulated data for natural and synthetic bullatanocin (squamostatin C)

S20-S23

${ }^{1} \mathrm{HNMR}$ and ${ }^{13} \mathrm{CNMR}$ spectra of selected compounds

S24-S70

Arabic numerals are used for compounds that are illustrated in the text. Roman numerals are used for synthetic intermediates that are not explicitly mentioned in the text, and appear in the supporting information only.

General. TLC was performed on aluminum sheets precoated with silica gel 60 (HF-254, E. Merck) to a thickness of $0.25 \mathrm{~mm}$. Flash column chromatography (FCC) was performed using Kieselgel 60 (230-400 mesh, E. Merck) and employed a stepwise solvent polarity gradient, correlated with TLC mobility. Unless otherwise stated, ${ }^{1} \mathrm{H}$ and ${ }^{13} \mathrm{C}$ NMR spectra were recorded at 300 and $75 \mathrm{MHz}$ respectively, in $\mathrm{CDCl}_{3}$ solutions, with $\mathrm{CHCl}_{3}$ as internal standard. High resolution mass spectroscopy was carried out at the Mass Spectrometry Facility at the University of Illinois at Urbana-Champaign. 
Iodoetherification of Isopropylidene alkenes 6 and 7 (For synthesis of 6 and 7 see ref. 8).
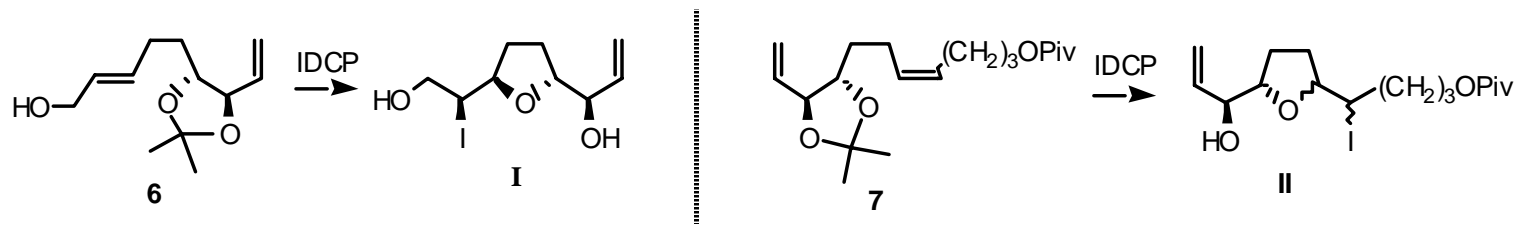

THF-iodide I. To a solution of alcohol 6 (6.97 g, $32.9 \mathrm{mmol})$ in 1\% water:acetonitrile $(175 \mathrm{~mL})$ was added IDCP (23.2 $\mathrm{g}, 49.0 \mathrm{mmol})$. The mixture was stirred at $\mathrm{rt}$ for $1 \mathrm{~h}$, then poured into saturated, aqueous $\mathrm{Na}_{2} \mathrm{~S}_{2} \mathrm{O}_{3}(150 \mathrm{~mL})$, and extracted with ether $(3 \times 100 \mathrm{~mL})$. The organic phase was dried $\left(\mathrm{Na}_{2} \mathrm{SO}_{4}\right)$, filtered and evaporated in vacuo. FCC of the residue gave $\mathbf{I}(8.70 \mathrm{~g}, 89 \%): \mathrm{R}_{\mathrm{f}}$ $=0.26(30 \%$ EtOAc:petroleum ether $) ;[\alpha]^{22}{ }_{\mathrm{D}}+24.7\left(c 8.10, \mathrm{CHCl}_{3}\right) ;{ }^{1} \mathrm{H} \mathrm{NMR}\left(\mathrm{C}_{6} \mathrm{D}_{6}, 500 \mathrm{MHz}\right) \delta$ $5.75(\mathrm{~m}, 1 \mathrm{H}), 5.38(\mathrm{~d}, \mathrm{~J}=17.5 \mathrm{~Hz}, 1 \mathrm{H}), 5.12(\mathrm{~d}, \mathrm{~J}=10.5 \mathrm{~Hz}, 1 \mathrm{H}), 4.00-4.40(\mathrm{~m}, 4 \mathrm{H}), 3.90$ (s, br, $3 \mathrm{H}), 2.10(\mathrm{~d}, 1 \mathrm{H}, J=9.0 \mathrm{~Hz}), 1.40-1.60(\mathrm{~m}, 4 \mathrm{H}) ;{ }^{13} \mathrm{C} \mathrm{NMR}\left(\mathrm{C}_{6} \mathrm{D}_{6}, 75 \mathrm{MHz}\right) \delta 137.7,117.0,84.0$, 82.4, 75.9, 67.7, 40.8, 34.3, 28.3; HRMS (ESI) calcd for $\mathrm{C}_{9} \mathrm{H}_{15} \mathrm{O}_{3} \mathrm{INa}(\mathrm{M}+\mathrm{Na})$ 320.9964, found 320.9964 .

THF-iodide mixture II. To a solution of pivaloyl ester 7 (6.78 g, $19.4 \mathrm{mmol})$ in 1\% water:acetonitrile (200 mL) was added IDCP (13.9 g, $29.0 \mathrm{mmol})$. The mixture was stirred at rt for $30 \mathrm{~min}$, then processed as described for the preparation of I. FCC of the crude residue afforded mixture II (6.27 g, 79\%): $\mathrm{R}_{\mathrm{f}}=0.23\left(10 \%\right.$ EtOAc:petroleum ether); $[\alpha]^{22}{ }_{\mathrm{D}}-8.7\left(c 0.60, \mathrm{CHCl}_{3}\right) ;{ }^{1} \mathrm{H}$ $\operatorname{NMR}\left(\mathrm{C}_{6} \mathrm{D}_{6}, 500 \mathrm{MHz}\right) \delta 5.75(\mathrm{~m}, 1 \mathrm{H}), 5.38(\mathrm{~d}, \mathrm{~J}=17.0 \mathrm{~Hz}, 1 \mathrm{H}), 5.07(\mathrm{~d}, \mathrm{~J}=11.0 \mathrm{~Hz}, 1 \mathrm{H}), \quad 3.90$ (s, br, 2H), 3.60-3.90 (m, 3H), $3.40(\mathrm{~s}, \mathrm{br}, 1 \mathrm{H}), 2.40(\mathrm{~s}, 1 \mathrm{H}), 1.30-1.90(\mathrm{~m}, 8 \mathrm{H}), 1.20(\mathrm{~s}, 9 \mathrm{H}) ;{ }^{13} \mathrm{C}$ 
$\operatorname{NMR}\left(\mathrm{CDCl}_{3}, 75 \mathrm{MHz}\right) \delta 179.0,137.2,117.8,83.9,83.2,76.2,64.0,40.9,39.5,33.3,31.8,29.8$, 29.0, 28.0; HRMS (FAB) calcd for $\mathrm{C}_{16} \mathrm{H}_{28} \mathrm{O}_{4} \mathrm{I}(\mathrm{M}+\mathrm{H})$ 411.1032, found 411.1030.

\section{Assignment of THF stereochemistry}

The stereochemistry of THF I was assigned by comparison of the ${ }^{13}$ CNMR data for selected carbinol carbons $\left(\mathrm{C}_{\mathrm{q}}-\mathrm{C}_{\mathrm{u}}\right)$ in the derived diol III-t and the stereochemically the reference trans/cis THF pair III-ref-t, and III-ref-c ${ }^{5 c}$ (Fig. 1). The stereochemistry in III-ref-c corresponds to the derivative that would have resulted from derivitization of the cis-THF diastereomer of $\mathbf{I}$ from the iodoetherification reaction. The data for $C_{p}$ was not considered because of the very different chemical environment of this carbon in III-t compared with III-ref-t and III-ref-c. Thus, $\Sigma|\Delta \delta|$ for III-t vs.III-ref-t and III-ref-c were 1.03 and 1.94 respectively. The stereochemistry of II-c and II-t was assigned in a similar fashion by comparison of the data for the derivatives IV-t and IV-c with reference pair IV-ref-t and IV-ref-c ${ }^{5 \mathrm{c}}(\Sigma|\Delta \delta|$ for IV-t vs IV-ref-t and IV-ref-c: 1.44 and 3.06 respectively; $\Sigma|\Delta \delta|$ for IV-c vs IV-ref-t and IV-ref-c: 2.68 and 0.86 respectively). 


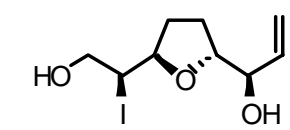

I
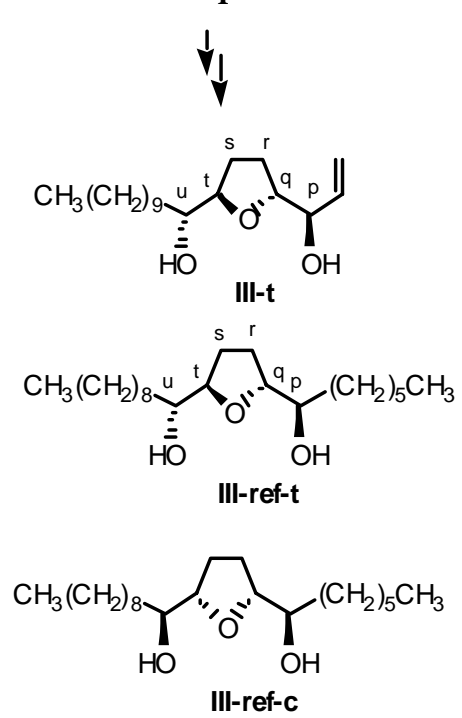



$\downarrow$
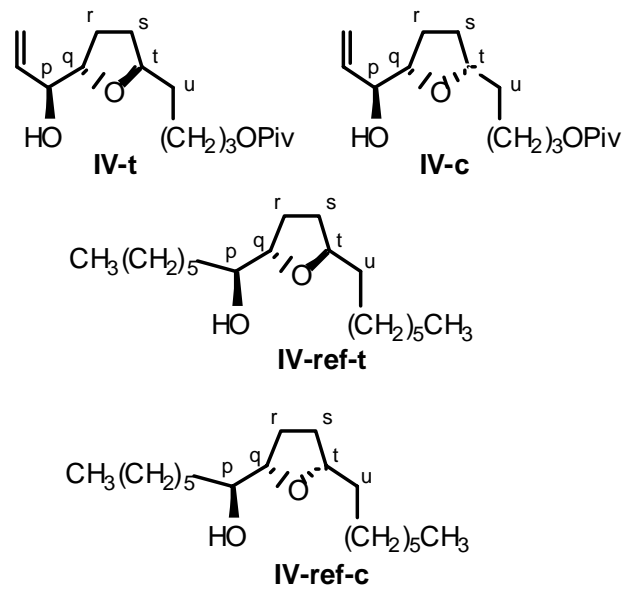

\begin{tabular}{llllllll} 
Carbon \# (ppm) & $\mathbf{p}$ & $\mathbf{q}$ & $\mathbf{r}$ & $\mathbf{s}$ & $\mathbf{t}$ & $\mathbf{u}$ & $\sum^{q \rightarrow u}|\Delta \delta|$ \\
\hline IV-t & 75.47 & 81.61 & 28.02 & 32.14 & 79.25 & 35.24 & - \\
IV-ref-t & 74.20 & 81.90 & 28.40 & 32.40 & 79.30 & 35.70 & - \\
$\Delta \delta$ (IV-t/IV-ref-t) & 1.27 & -0.29 & -0.38 & -0.26 & -0.05 & -0.46 & $1.44^{*}$ \\
IV-ref-c & 74.50 & 82.20 & 27.80 & 31.40 & 79.90 & 36.10 & - \\
$\Delta \delta$ (IV-t/IV-ref-c) & 0.97 & -0.59 & 0.22 & 0.74 & -0.65 & -0.86 & 3.06 \\
IV-c & 76.12 & 82.10 & 27.79 & 31.62 & 80.21 & 35.88 & - \\
$\Delta \delta$ (IV-c/IV-ref-t) & 1.92 & 0.20 & -0.61 & -0.78 & 0.91 & 0.18 & 2.68 \\
$\Delta \delta$ (IV-c/IV-ref-c) & 1.62 & -0.10 & -0.01 & 0.22 & 0.31 & -0.22 & $0.86^{*}$ \\
III-t & 75.72 & 83.13 & 28.67 & 28.77 & 82.50 & 74.24 & - \\
III-ref-t & 74.00 & 82.70 & 28.80 & 28.80 & 82.70 & 74.00 & - \\
$\Delta \delta$ (III-t/III-ref-t) & 1.72 & 0.43 & -0.13 & -0.03 & -0.20 & 0.24 & $1.03^{*}$ \\
III-ref-c & 74.30 & 82.80 & 28.10 & 28.10 & 82.80 & 74.30 & - \\
$\Delta \delta$ (III-t/III-ref-c) & 1.42 & 0.33 & 0.57 & 0.67 & -0.30 & -0.06 & 1.93
\end{tabular}

* denotes the synthetic compound/reference trans- or cis- THF that gives the better match. 
$\Delta \delta(I V-t / I V-r e f-t)$

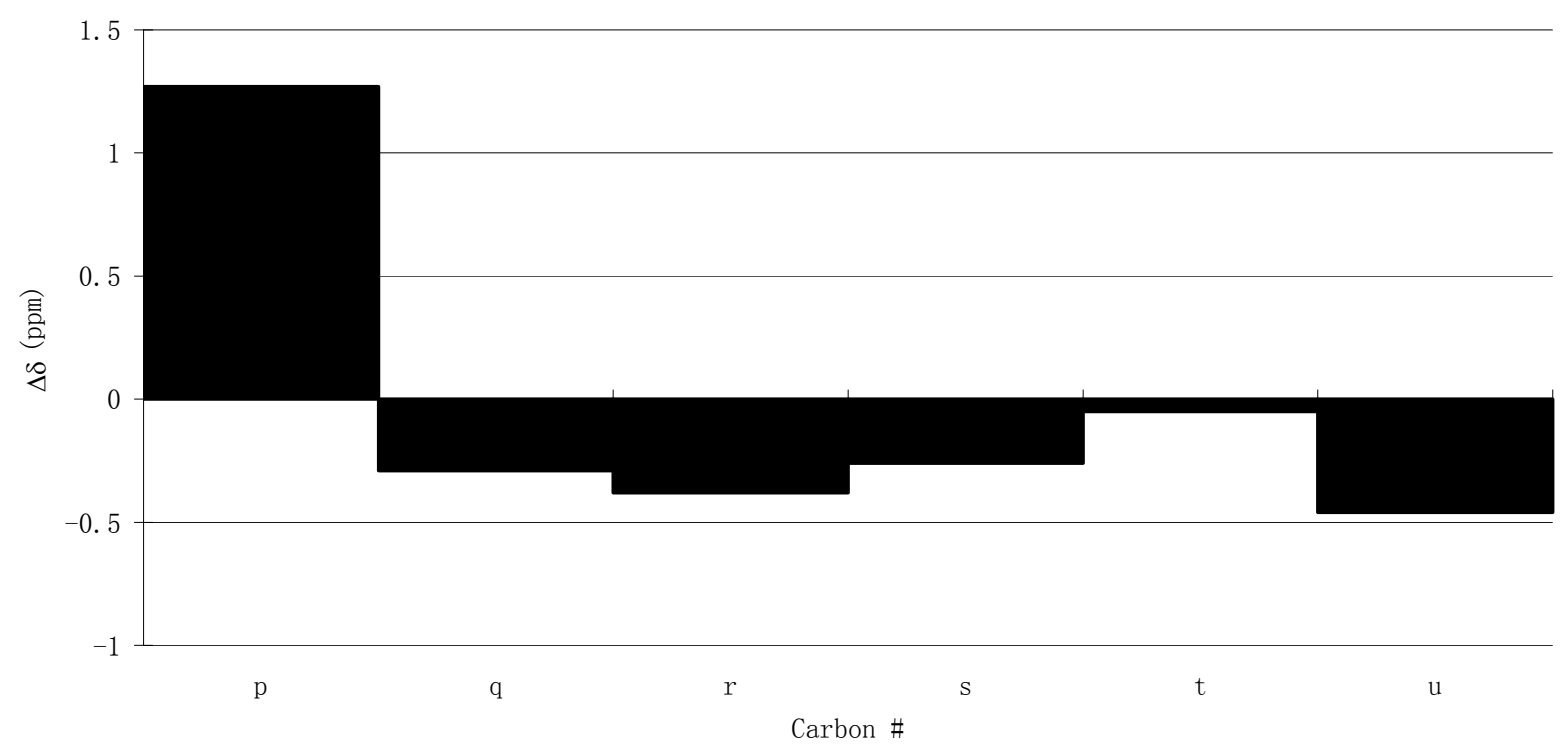

$\Delta \delta(\mathrm{IV}-\mathrm{t} / \mathrm{IV}-\mathrm{ref}-\mathrm{c})$

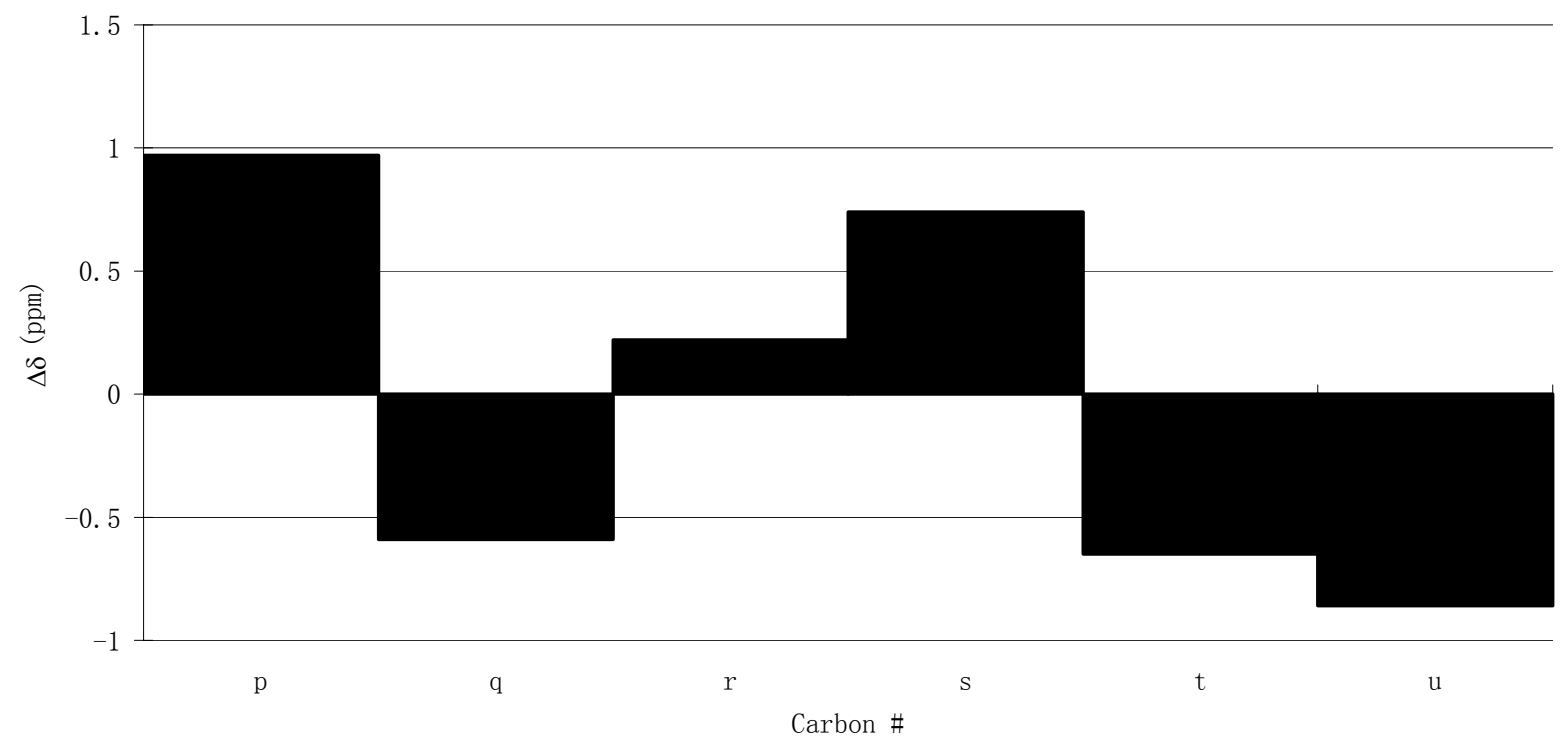


$\Delta \delta(\mathrm{IV}-\mathrm{c} / \mathrm{IV}-\mathrm{ref}-\mathrm{t})$

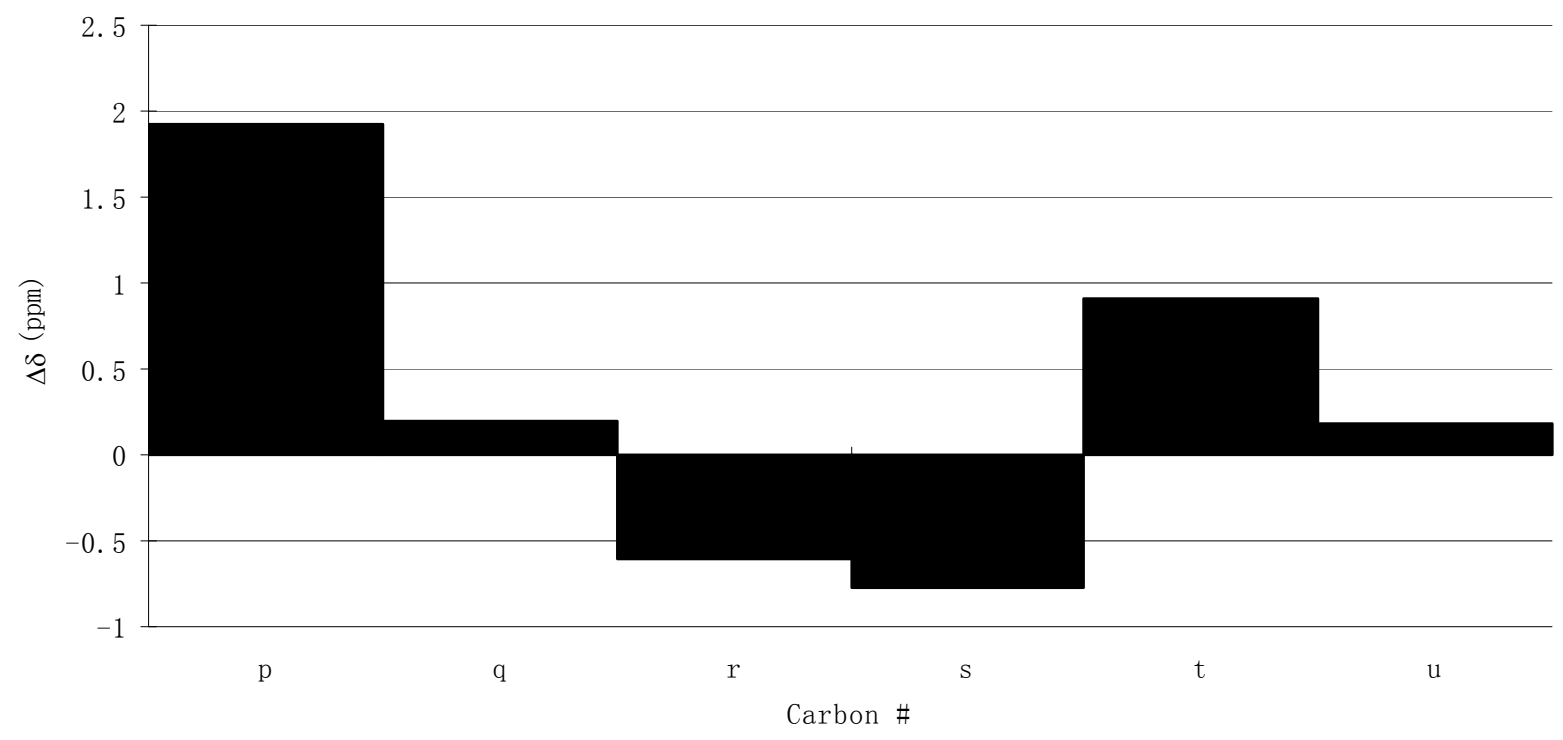

$\Delta \delta(\mathrm{IV}-\mathrm{c} / \mathrm{IV}-\mathrm{ref}-\mathrm{c})$

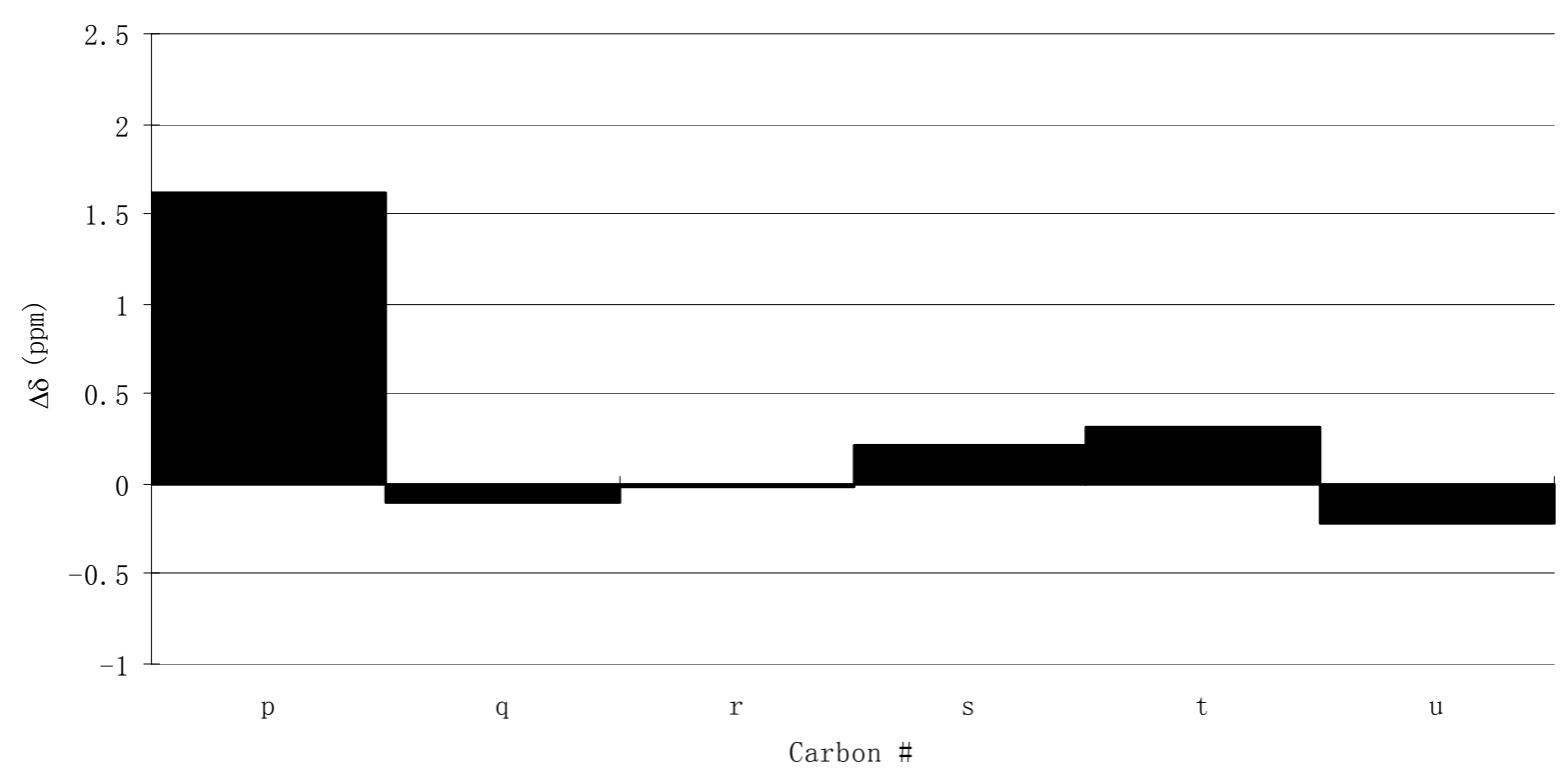


$\Delta \delta(\mathrm{III}-\mathrm{t} / \mathrm{III}-\mathrm{ref}-\mathrm{t})$

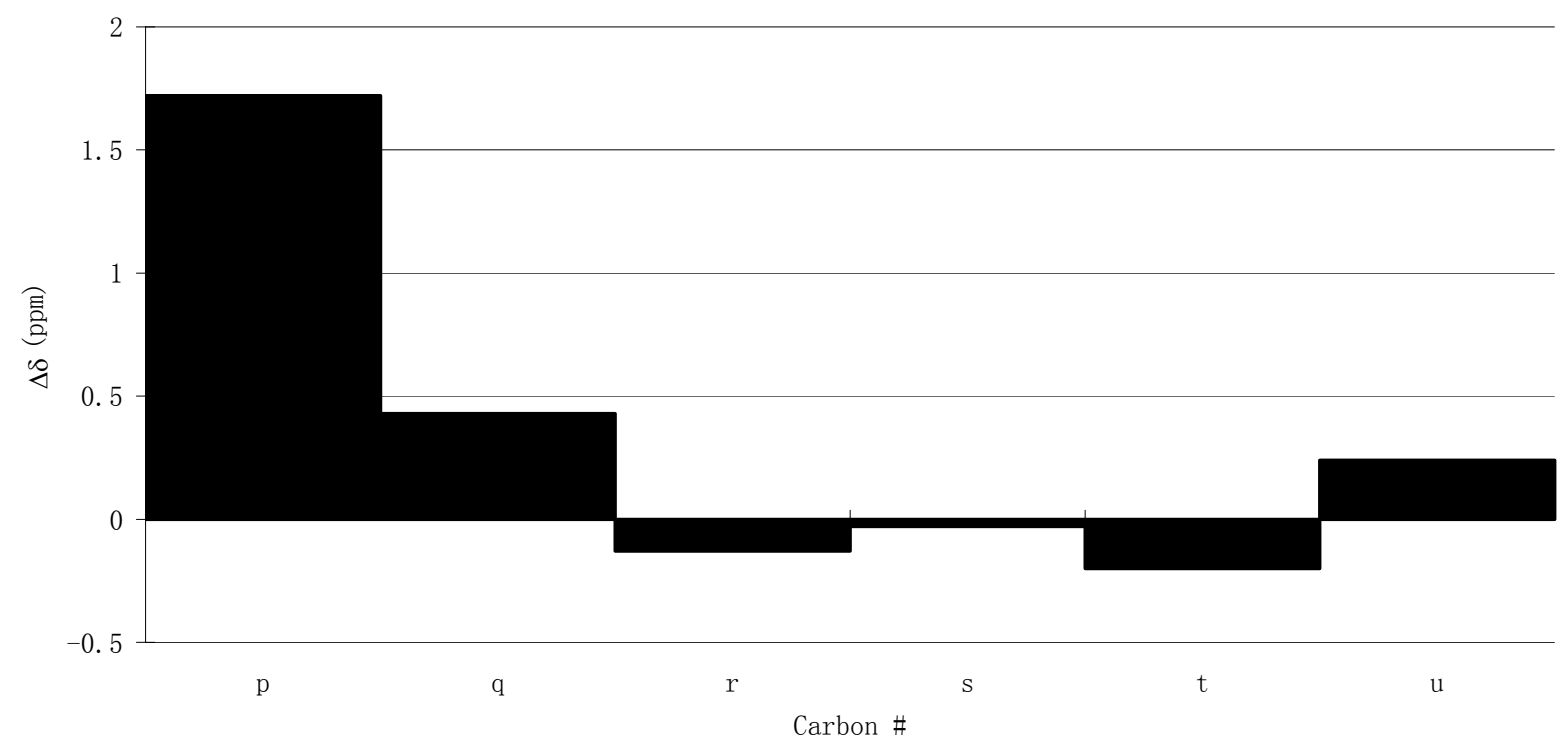

$\Delta \delta($ III-t/III-ref-c)

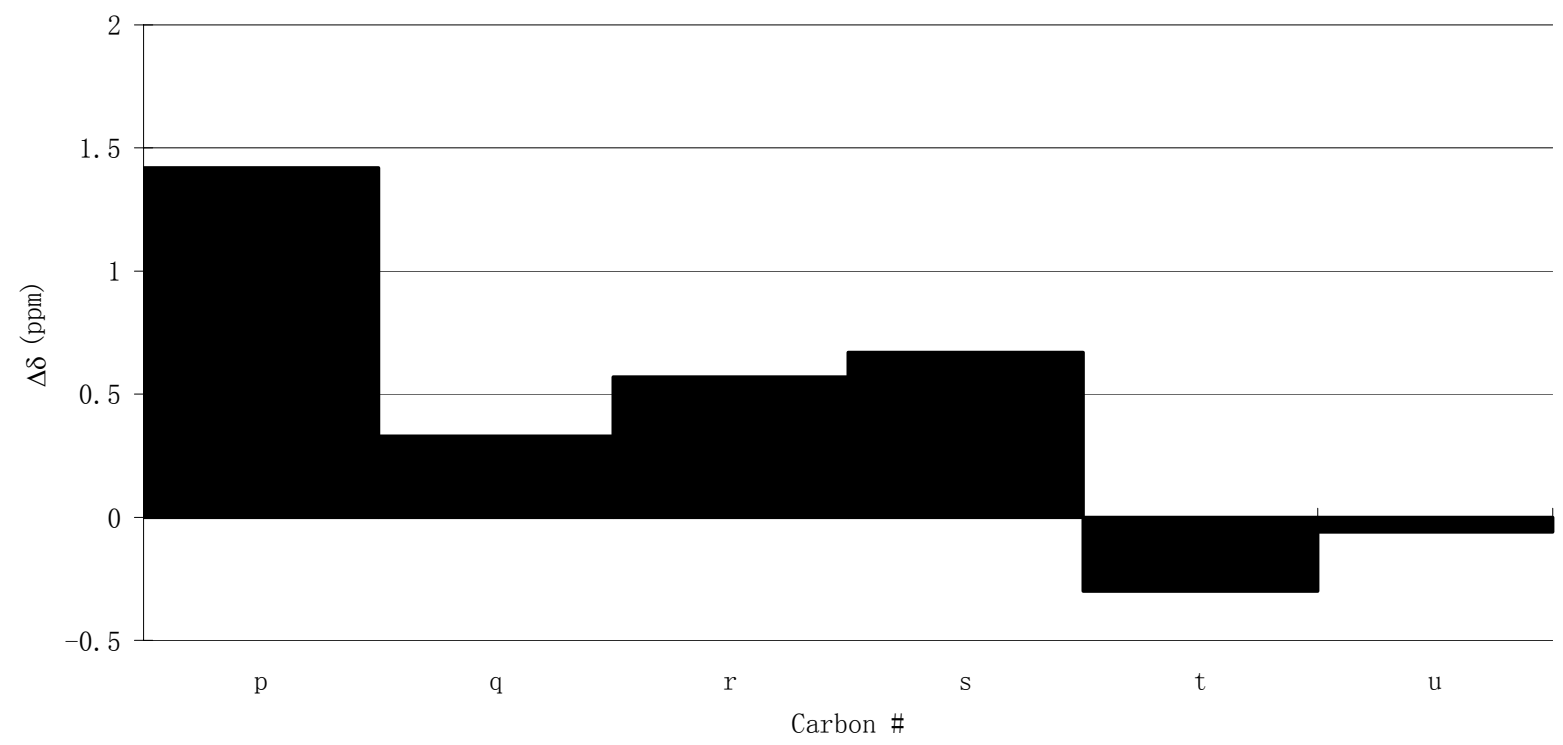


Physical data for THF-alkenes 4 and 5 (For conversion of I and II to 4 and 5 respectively, see ref. 8).
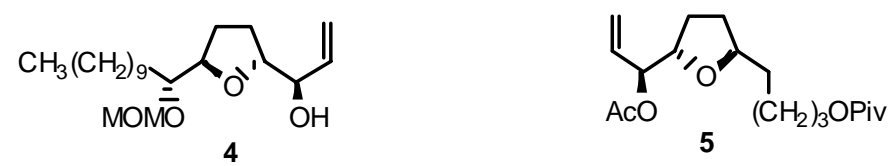

THF-alkene 4. $\mathrm{R}_{\mathrm{f}}=0.88$ (50\% EtOAc:petroleum ether); $[\alpha]^{22}{ }_{\mathrm{D}}+20.9\left(\right.$ c $\left.1.31, \mathrm{CHCl}_{3}\right) ;{ }^{1} \mathrm{H} \mathrm{NMR}$ $\left(\mathrm{CDCl}_{3}, 300 \mathrm{MHz}\right) \delta 5.7-5.9(\mathrm{~m}, 1 \mathrm{H}), 5.10-5.40(\mathrm{dd}, 2 \mathrm{H}, J=17.2,10.6 \mathrm{~Hz}), 4.75(\mathrm{~d}, 1 \mathrm{H}, J=7.0)$, $4.65(\mathrm{~d}, 1 \mathrm{H}, J=6.6 \mathrm{~Hz}), 3.80-4.10(\mathrm{~m}, 3 \mathrm{H}), 3.40-3.50(\mathrm{~m}, 1 \mathrm{H}), 3.40(\mathrm{~s}, 3 \mathrm{H}), 2.70(\mathrm{~s}, 1 \mathrm{H})$, $1.80-2.00(\mathrm{~m}, 2 \mathrm{H}), 1.60-1.80(\mathrm{~m}, 2 \mathrm{H}), 1.30-1.50(\mathrm{~m}, 2 \mathrm{H}), 1.20-1.30(\mathrm{~s}, \mathrm{br}, 16 \mathrm{H}), 0.85(\mathrm{t}, 3 \mathrm{H}, J=$ $5.5 \mathrm{~Hz}) ;{ }^{13} \mathrm{C} \mathrm{NMR}\left(\mathrm{CDCl}_{3}, 75 \mathrm{MHz}\right) \delta 137.6,117.3,97.4,82.7,82.3,80.5,76.0,56.3,32.6,32.0$, $30.5,30.3,30.0,29.2,28.7,26.2,23.4,14.8$; HRMS (FAB) calcd for $\mathrm{C}_{19} \mathrm{H}_{35} \mathrm{O}_{3}\left(\mathrm{M}-\mathrm{OCH}_{3}\right)$ 311.2586, found 311.2585.

THF-alkene 5. $\mathrm{R}_{\mathrm{f}}=0.81$ (30\% EtOAc:petroleum ether); ${ }^{1} \mathrm{H}$ NMR $\left(\mathrm{CDCl}_{3}, 300 \mathrm{MHz}\right) \delta$ 5.70-5.85 (m, 1H), 5.1-5.3 (m, 3H), $4.0(\mathrm{~m}, 3 \mathrm{H}), 3.9(\mathrm{~m}, 1 \mathrm{H}), 2.1(\mathrm{~s}, 3 \mathrm{H}), 1.90-2.05(\mathrm{~m}, 2 \mathrm{H})$, 1.5-1.7 (m, 4H), 1.3-1.5 (m, 4H), $1.2(\mathrm{~s}, \mathrm{br}, 9 \mathrm{H}) ;{ }^{13} \mathrm{C} \mathrm{NMR}\left(\mathrm{CDCl}_{3}, 75 \mathrm{MHz}\right) \delta 178.3,170.0$, $133.5,118.4,79.4,79.3,76.4,64.3,38.9,35.30,32.0,28.9,28.2,27.4,22.8,21.3$; HRMS (FAB) calcd for $\mathrm{C}_{18} \mathrm{H}_{31} \mathrm{O}_{5}(\mathrm{M}+\mathrm{H})$ 327.2171, found 327.2170. 


\section{Cross Metathesis}
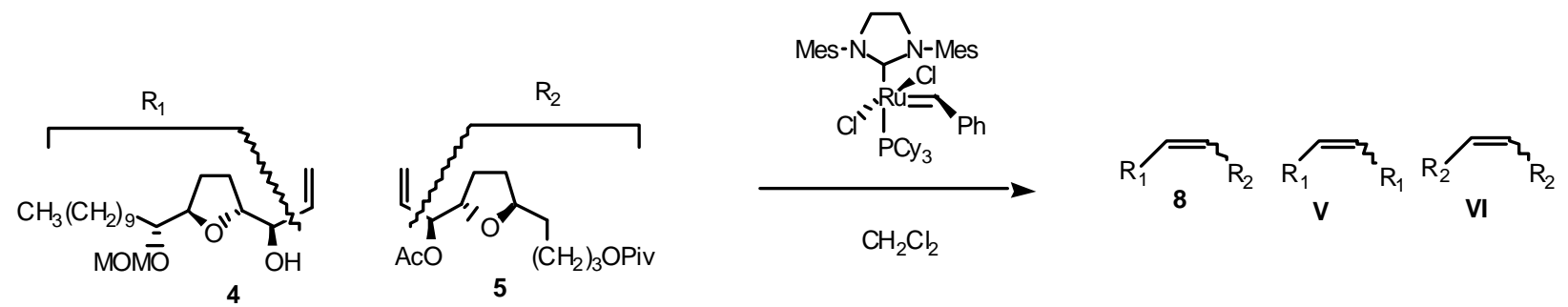

Method A. Grubb's catalyst (34 mg, $0.04 \mathrm{mmol})$ in $\mathrm{CH}_{2} \mathrm{Cl}_{2}(3 \mathrm{~mL})$ was injected, at rt, into a degassed solution of alcohol 4 (134 mg, $0.39 \mathrm{mmol})$, and ester 5 (491 $\mathrm{mg}, 1.50 \mathrm{mmol})$, in $\mathrm{CH}_{2} \mathrm{Cl}_{2}(20 \mathrm{~mL})$. After $18 \mathrm{~h}$ at this temperature, additional catalyst (34 $\left.\mathrm{mg}, 0.04 \mathrm{mmol}\right)$ in $\mathrm{CH}_{2} \mathrm{Cl}_{2}(3 \mathrm{~mL})$ was introduced. The reaction was stirred for an additional $18 \mathrm{~h}$ at $\mathrm{rt}$, then quenched by addition of DMSO $(142 \mu \mathrm{L})$, stirred for an additional $18 \mathrm{~h}$ and concentrated in vacuo. FCC of the residue (10-20\% EtOAc:petroleum ether) led to recovered 5 (19 mg), 8 (212 $\mathrm{mg}, 98 \%$ relative to $4,46 \%$ relative to 5$)$ and $\mathrm{VI}(14 \mathrm{mg}, 3 \%)$.

Method B. Grubb's catalyst $(28.5 \mathrm{mg}, 0.034 \mathrm{mmol})$ in $\mathrm{CH}_{2} \mathrm{Cl}_{2}(3 \mathrm{~mL})$ was injected, at rt, into a degassed solution of alcohol 4 (115 mg, $0.34 \mathrm{mmol})$ and ester 5 (322 $\mathrm{mg}, 0.98 \mathrm{mmmol})$, in $\mathrm{CH}_{2} \mathrm{Cl}_{2}(20 \mathrm{~mL})$. After $18 \mathrm{~h}$ at this temperature, additional catalyst $(28.5 \mathrm{mg}, 0.034 \mathrm{mmol})$ in $\mathrm{CH}_{2} \mathrm{Cl}_{2}(3 \mathrm{~mL})$ was introduced. The reaction was stirred for $18 \mathrm{~h}$ at reflux, then quenched by addition of DMSO $(119 \mu \mathrm{L})$, and processed as in method A. Purification of the crude residue provided 8 (160.7 $\mathrm{mg}, 75 \%$ relative to $3,76 \%$ relative to 4$), \mathbf{V}(<5 \mathrm{mg}$, ca $4 \%)$ and $\mathbf{V I}(<5 \mathrm{mg}$, ca $2 \%$ ).

Bis-THF alkene 8: $\mathrm{R}_{\mathrm{f}}=0.53$ (40\% EtOAc:petroleum ether); ${ }^{1} \mathrm{H} \mathrm{NMR}\left(\mathrm{CDCl}_{3}, 500 \mathrm{MHz}\right) \delta 5.70$ 
(m, 2H), $5.20(\mathrm{~m}, 1 \mathrm{H}), 4.75(\mathrm{~d}, 1 \mathrm{H}, J=7.0), 4.65(\mathrm{~d}, 1 \mathrm{H}, J=6.5 \mathrm{~Hz}), 4.00(\mathrm{~m}, 3 \mathrm{H}), 3.8-4.0(\mathrm{~m}$, 4H), $3.45(\mathrm{~m}, 1 \mathrm{H}), 3.36(\mathrm{~s}, 3 \mathrm{H}), 2.70\left(\mathrm{~s}, \mathrm{br}, 1 \mathrm{H}, \mathrm{D}_{2} \mathrm{O}\right.$ ex), $2.04(\mathrm{~s}, 3 \mathrm{H}), 1.90-2.00(\mathrm{~m}, 4 \mathrm{H})$, $1.50-1.70(\mathrm{~m}, 6 \mathrm{H}), 1.30-1.50(\mathrm{~m}, 6 \mathrm{H}), 1.22(\mathrm{~s}, \mathrm{br}, 16 \mathrm{H}), 1.16(\mathrm{~s}, 9 \mathrm{H}), 0.85(\mathrm{t}, 3 \mathrm{H}, J=6.5 \mathrm{~Hz})$;

${ }^{13} \mathrm{C} \mathrm{NMR}\left(\mathrm{CDCl}_{3}, 75 \mathrm{MHz}\right) \delta 178.9,170.5,133.9,128.0,97.4,82.7,82.3,80.4,79.9,79.81,76.4$, $75.0,64.9,56.4,39.4,35.8,32.6,32.6,32.0,30.5,30.3,30.0,29.4,29.2,28.8,28.7,28.0,26.2$, 23.4, 21.9, 14.8; HRMS (FAB) calcd for $\mathrm{C}_{36} \mathrm{H}_{64} \mathrm{O}_{9} \mathrm{Na}(\mathrm{M}+\mathrm{Na}) 663.4448$, found 663.4451 .

Bis-THF alkene V: $\mathrm{R}_{\mathrm{f}}=0.08$ (20\% EtOAc:petroleum ether); ${ }^{1} \mathrm{H}$ NMR $\left(\mathrm{CDCl}_{3}, 300 \mathrm{MHz}\right) \delta 5.75$ $(\mathrm{m}, 2 \mathrm{H}), 4.80(\mathrm{~d}, 2 \mathrm{H}, J=6.6 \mathrm{~Hz}), 4.70(\mathrm{~d}, 2 \mathrm{H}, J=7.0 \mathrm{~Hz}), 3.8-4.0(\mathrm{~m}, 6 \mathrm{H}), 3.45(\mathrm{~m}, 2 \mathrm{H}), 3.35(\mathrm{~s}$, $6 \mathrm{H}), 2.70(\mathrm{~s}, \mathrm{br}, 2 \mathrm{H}), 1.90-2.10(\mathrm{~m}, 4 \mathrm{H}), 1.50-1.80(\mathrm{~m}, 4 \mathrm{H}), 1.30-1.50(\mathrm{~m}, 4 \mathrm{H}), 1.22(\mathrm{~s}, \mathrm{br}, 32 \mathrm{H})$, $0.85(\mathrm{t}, 6 \mathrm{H}, J=6.5 \mathrm{~Hz}) ;{ }^{13} \mathrm{C} \mathrm{NMR}\left(\mathrm{CDCl}_{3}, 75 \mathrm{MHz}\right) \delta 131.6,97.5,82.9,82.3,80.5,75.2,56.4$, 32.6, 32.0, 30.6, 30.3, 30.0, 29.3, 28.8, 26.2, 23.4, 14.8; HRMS (ESI) calcd for $\mathrm{C}_{38} \mathrm{H}_{72} \mathrm{O}_{8} \mathrm{Na}$ (M + Na) 679.5125, found 679.5128 .

Bis-THF alkene VI: $\mathrm{R}_{\mathrm{f}}=0.28$ (15\% EtOAc: petroleum ether); ${ }^{1} \mathrm{H} \mathrm{NMR}\left(\mathrm{CDCl}_{3}, 300 \mathrm{MHz}\right) \oint 5.7$ $(\mathrm{m}, 2 \mathrm{H}), 5.2(\mathrm{~m}, 2 \mathrm{H}), 3.85-4.15(\mathrm{~m}, 8 \mathrm{H}),(\mathrm{m}, 8 \mathrm{H}), 2.1(\mathrm{~s}, 6 \mathrm{H}), 1.9-2.0(\mathrm{~m}, 4 \mathrm{H}), 1.6-1.8(\mathrm{~m}, 8 \mathrm{H})$, 1.4-1.6 (m, 8H), $1.22(\mathrm{~s}, 18 \mathrm{H}) .{ }^{13} \mathrm{C} \mathrm{NMR}\left(\mathrm{CDCl}_{3}, 75 \mathrm{MHz}\right) \delta 178.6,170.1,129.6,79.6,79.3$, 75.7, 64.5, 39.0, 35.4, 32.1, 29.0, 28.3, 27.5, 22.9, 21.5; HRMS (ESI) calcd for $\mathrm{C}_{34} \mathrm{H}_{56} \mathrm{O}_{10} \mathrm{Na}(\mathrm{M}$ + Na) 647.3771, found 647.3785. 


\section{Alcohol 9}

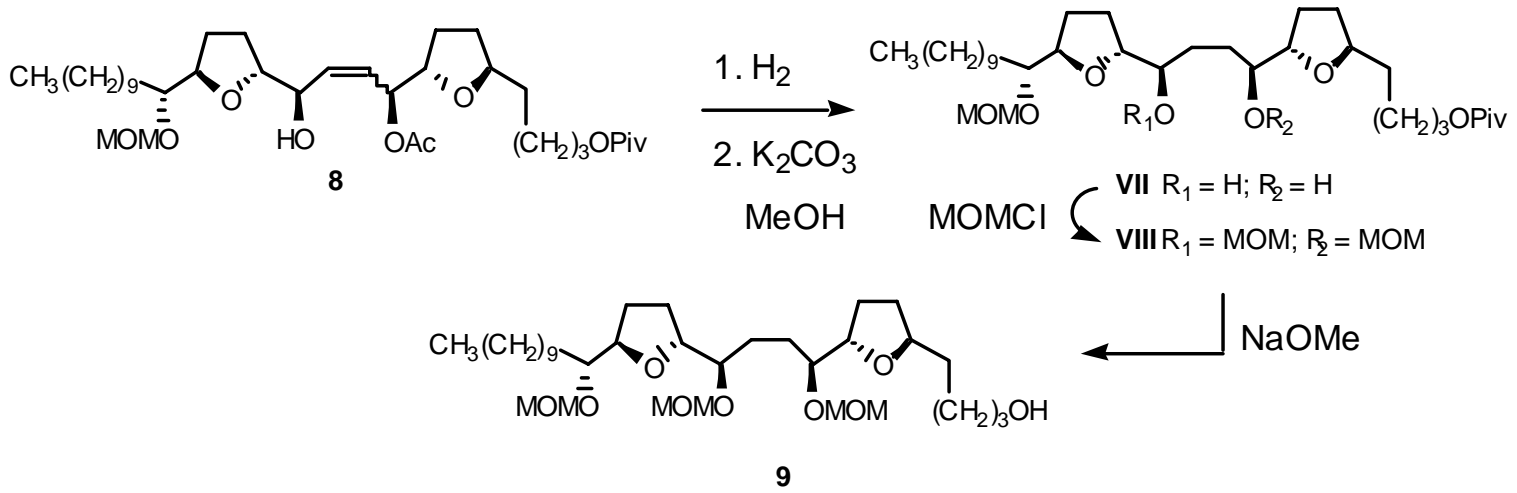

\section{Compound VII}

A mixture of alkene $8(800 \mathrm{mg}, 1.25 \mathrm{mmol})$ and $10 \% \mathrm{Pd} / \mathrm{C}(80 \mathrm{mg})$ in ethyl acetate $(60 \mathrm{~mL})$ was stirred under an atmosphere of hydrogen (balloon) at rt, for $18 \mathrm{~h}$. The suspension was then filtered through celite, the filtrate concentrated under reduced pressure, and the residue $(778.8 \mathrm{mg}) \mathrm{used}$ directly in the next step.

A portion of the material from the previous step $(56 \mathrm{mg})$ dissolved in dry methanol $(5 \mathrm{~mL})$ and treated with $\mathrm{K}_{2} \mathrm{CO}_{3}(12 \mathrm{mg}, 0.087 \mathrm{mmol})$. The reaction mixture was stirred for $18 \mathrm{~h}$ at $\mathrm{rt}$, then neutralise by $5 \% \mathrm{HCl}$, and extracted with EtOAc $(3 \times 10 \mathrm{ml})$ after evaporate most methanol. The combined organic phase was dried $\left(\mathrm{Na}_{2} \mathrm{SO}_{4}\right)$, filted and evaporated in vacuo. FCC of the residue (50\% EtOAc/50\% $\left.\mathrm{CHCl}_{3}\right)$ afforded diol VII (29 mg, 91\% from 8): $\mathrm{R}_{\mathrm{f}}=0.41(50 \%$ EtOAc:50\%

petroleum ether); ${ }^{1} \mathrm{H} \mathrm{NMR}\left(\mathrm{CDCl}_{3}, 500 \mathrm{MHz}\right) \delta 4.75$ (d, 1H, $\left.J=7.0 \mathrm{~Hz}\right), 4.65(\mathrm{~d}, 1 \mathrm{H}, J=7.0$ Hz), $4.0(\mathrm{~m}, 3 \mathrm{H}), 3.91(\mathrm{~m}, 1 \mathrm{H}), 3.85(\mathrm{~m}, 1 \mathrm{H}), 3.75(\mathrm{~m}, 3 \mathrm{H}), 3.45(\mathrm{~m}, 1 \mathrm{H}), 3.35(\mathrm{~s}, 3 \mathrm{H}), 2.7$ (s, br, 2H), 1.9-2.0 (m, 4H), 1.5-1.7 (m, 6H), 1.3-1.5 (m, 10H), $1.22(\mathrm{~s}$, br, 16H), $1.15(\mathrm{~s}, 9 \mathrm{H}), 0.85(\mathrm{t}$, $3 \mathrm{H}, J=6.5 \mathrm{~Hz}) ;{ }^{13} \mathrm{C} \mathrm{NMR}\left(\mathrm{CDCl}_{3}, 75 \mathrm{MHz}\right) \oint 178.9,97.4,83.2,82.7,82.2,80.5,79.7,75.1,74.9$, $64.8,56.3,39.4,36.0,33.1,32.6,32.0,30.6,30.5,30.3,30.0,29.4,29.1,27.9,26.2,23.3,14.7$.

\section{Compound VIII}

$\operatorname{MOMCl}(54 \mu \mathrm{L}, 0.7 \mathrm{mmol})$ was added to a solution of diol VII (105 mg, $0.18 \mathrm{mmol})$ and i- $\mathrm{Pr}_{2} \mathrm{Net}(305 \mu \mathrm{L}, 1.75 \mathrm{mmol})$ in anhydrous $\mathrm{CH}_{2} \mathrm{Cl}_{2}(20 \mathrm{~mL})$ at $0{ }^{\circ} \mathrm{C}$. The mixture was stirred for 
$24 \mathrm{~h}$ at $\mathrm{rt}$, then quenched with saturated aqueous $\mathrm{NH}_{4} \mathrm{Cl}$ and extracted with ether $(3 \times 20 \mathrm{~mL})$. The organic layer was washed with water and brine, dried $\left(\mathrm{Na}_{2} \mathrm{SO}_{4}\right)$, filtered and evaporated under reduced pressure. FCC of the residue gave VIII $(120 \mathrm{mg}, 100 \%): \mathrm{R}_{\mathrm{f}}=0.64(30 \%$ EtOAc:70\% petroleum ether); $[\alpha]^{22}{ }_{\mathrm{D}}+20.9$ (c 11.6, $\left.\mathrm{CHCl}_{3}\right) ;{ }^{1} \mathrm{H}$ NMR $\left(\mathrm{CDCl}_{3}, 500 \mathrm{MHz}\right) \delta 4.83$ $(\mathrm{m}, 3 \mathrm{H}), 4.65(\mathrm{~m}, 3 \mathrm{H}), 4.00(\mathrm{t}, 2 \mathrm{H}, J=6.59 \mathrm{~Hz}), 3.95(\mathrm{~m}, 3 \mathrm{H}), 3.85(\mathrm{~m}, 1 \mathrm{H}), 3.45(\mathrm{~m}, 3 \mathrm{H}), 3.35$ (s, 9H), 1.90-2.00 (m, 4H), 1.50-1.80 (m, 8H), 1.30-1.50 (m, 8H), 1.24 (s, br, 16H), $1.17(\mathrm{~s}, 9 \mathrm{H})$, $0.85(\mathrm{t}, 3 \mathrm{H}, J=6.5 \mathrm{~Hz}) ;{ }^{13} \mathrm{C} \mathrm{NMR}\left(\mathrm{CDCl}_{3}, 75 \mathrm{MHz}\right) \delta 179.0,97.4,82.2,81.6,80.7,80.4,79.7$, $64.9,56.4,39.5,36.1,33.0,32.6,32.1,30.6,30.3,30.0,29.5,29.3,29.2,28.0,26.3,23.5,23.4$, 14.8; HRMS (ESI) calcd for $\mathrm{C}_{38} \mathrm{H}_{72} \mathrm{O}_{10}(\mathrm{M}+\mathrm{Na}) 711.5023$, found 711.5032.

\section{Alcohol 9}

Sodium methoxide (162 mg, $3 \mathrm{mmol}$ ) was added to a solution of pivalate VIII (417 $\mathrm{mg}, 0.6$ $\mathrm{mmol})$ in anhydrous $\mathrm{MeOH}(30 \mathrm{~mL})$ at $\mathrm{rt}$. The mixture was heated at reflux for $12 \mathrm{~h}$, then cooled to $\mathrm{rt}$ and neutralized with $5 \%$ aqueous $\mathrm{HCl}$. Most of the methanol was evaporated under reduced pressure and the residue extracted with EtOAc $(3 \times 30 \mathrm{~mL})$. The organic layer was washed with water and brine, dried $\left(\mathrm{Na}_{2} \mathrm{SO}_{4}\right)$, filtered and concentrated in vacuo. FCC of the residue afforded recovered VIII (11 mg) and alcohol 9 (344 mg, 95\% based on recovered VIII): $\mathrm{R}_{\mathrm{f}}=0.17(60 \%$ EtOAc:40\% petroleum ether); ${ }^{1} \mathrm{H}$ NMR $\left(\mathrm{CDCl}_{3}, 500 \mathrm{MHz}\right) \delta 4.75(\mathrm{~m}, 3 \mathrm{H}), 4.65(\mathrm{~m}, 3 \mathrm{H})$, 3.80-4.00 (m, 4H), $3.55(\mathrm{t}, 2 \mathrm{H}, J=6.41 \mathrm{~Hz}), 3.40(\mathrm{~m}, 3 \mathrm{H}), 3.3(\mathrm{~s}, 9 \mathrm{H}), 1.8-2.0(\mathrm{~m}, 5 \mathrm{H}), 1.3-1.7$

$(\mathrm{m}, 16 \mathrm{H}), 1.22(\mathrm{~s}, \mathrm{br}, 16 \mathrm{H}), 0.85(\mathrm{t}, 3 \mathrm{H}, J=6.5 \mathrm{~Hz}) ;{ }^{13} \mathrm{C} \mathrm{NMR}\left(\mathrm{CDCl}_{3}, 75 \mathrm{MHz}\right) \delta 96.9,81.7$, 81.0, 80.2, 79.8, 79.3, 62.8, 55.9, 35.7, 33.0, 32.5, 32.1, 31.5, 30.0, 29.8, 29.5, 28.7, 28.7, 27.4, 25.8, 22.9, 22.8, 14.3; HRMS (FAB) calcd for $\mathrm{C}_{33} \mathrm{H}_{65} \mathrm{O}_{9}(\mathrm{M}+\mathrm{H})$ 605.4629, found 605.4629. 
Tetraol 12 and 12-tetra-(R)-MTPA ester

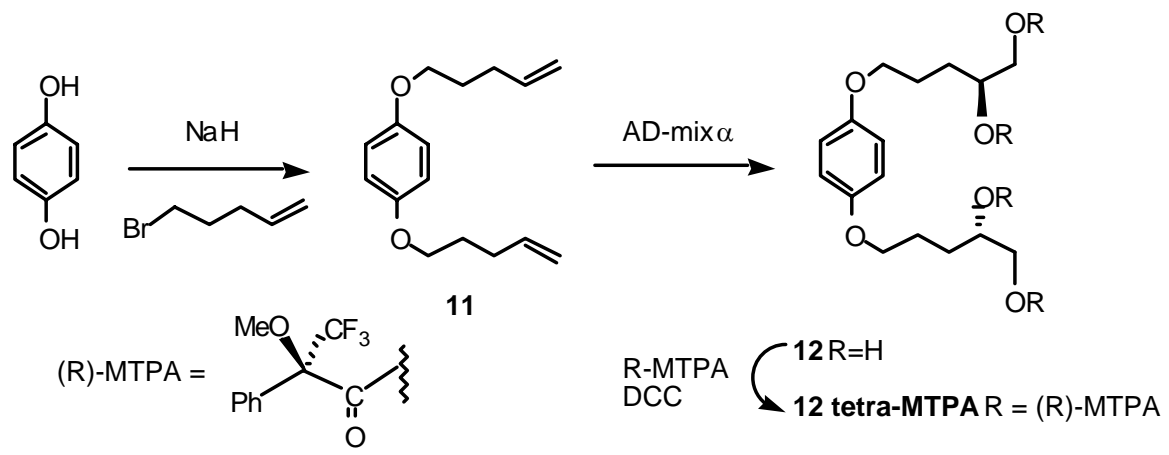

A suspension of sodium hydride (3.8 g, 60\% in mineral oil, $94.6 \mathrm{mmol})$ in DMF (100 mL) was stirred at rt for 2h. 5-bromo-1-pentene $(25 \mathrm{~g}, 129 \mathrm{mmol})$ was then introduced dropwise. The reaction mixture was warmed to $100{ }^{\circ} \mathrm{C}$ and stirred for an additional $10 \mathrm{~h}$ at this temperature. The mixture was then cooled to $\mathrm{rt}$, poured into water and extracted with diethyl ether $(3 \mathrm{x} 100 \mathrm{~mL})$. The combined organic phase was washed with brine, dried $\left(\mathrm{Na}_{2} \mathrm{SO}_{4}\right)$, and concentrated under reduced pressure. FCC of the residue afforded diene 11 (9.8 g, 93\%): $\mathrm{R}_{\mathrm{f}}=0.30$ (petroleum ether); ${ }^{1} \mathrm{H}$ NMR $\left(\mathrm{CDCl}_{3}, 300 \mathrm{MHz}\right) \delta 6.8(\mathrm{~s}, 4 \mathrm{H}), 5.8-5.9(\mathrm{~m}, 2 \mathrm{H})$, 5.00-5.10 (m, 4H), $3.90(\mathrm{t}, 4 \mathrm{H}, J=$ $6.5 \mathrm{~Hz}), 2.25(\mathrm{q}, 4 \mathrm{H}, J=7 \mathrm{~Hz}), 1.85(\mathrm{~m}, 4 \mathrm{H}) ;{ }^{13} \mathrm{C} \mathrm{NMR}\left(\mathrm{CDCl}_{3}, 75 \mathrm{MHz}\right) \oint 153.3,138.0,115.6$, 115.2, 68.1, 30.4, 28.9; HRMS (FAB) calcd for $\mathrm{C}_{16} \mathrm{H}_{22} \mathrm{O}_{2} 246.1619$, found 246.1621.

A $1000 \mathrm{~mL}$ round-bottomed flask, equipped with a magnetic stirrer, was charged with t-BuOH $(400 \mathrm{~mL})$, water $(400 \mathrm{~mL})$, and AD-mix- $\alpha(150 \mathrm{~g})$. Stirring at room temperature produced two clear phases. The mixture was cooled to $0{ }^{\circ} \mathrm{C}$ and diene 11 (20 g, $\left.81.3 \mathrm{mmol}\right)$ added. The heterogeneous slurry was stirred vigorously at $0{ }^{\circ} \mathrm{C}$ for $10 \mathrm{~h}$ (reaction progress was monitored by TLC). $\mathrm{Na}_{2} \mathrm{SO}_{3}(160 \mathrm{~g})$ was then added, the mixture warmed to rt, stirred for an additional $1 \mathrm{~h}$ at this temperature and diluted with ethyl acetate $(300 \mathrm{~mL})$. The organic layer was separated and the aqueous layer was further extracted with ethyl acetate $(3 \times 300 \mathrm{~mL})$ and an ethyl acetate/ethanol mixture $(4: 1)(3 \times 100 \mathrm{~mL})$. The combined organic extract was dried $\left(\mathrm{Na}_{2} \mathrm{SO}_{4}\right)$, filtered, and concentrated to give a white solid. The crude product was recrystallized three times from ethyl acetate to yield tetraol $12(16.5 \mathrm{~g}, 65 \%): \mathrm{R}_{\mathrm{f}}=0.62(10 \% \mathrm{MeOH}: \mathrm{EtOAc}) ; \mathrm{mp}=$ 
118.0-118.5 ${ }^{\circ} \mathrm{C}{ }^{1} \mathrm{H}$ NMR (DMSO-d 6 , $\left.300 \mathrm{MHz}\right) \oint 6.00(\mathrm{~s}, 4 \mathrm{H}), 3.68(\mathrm{t}, 4 \mathrm{H}, J=5.1 \mathrm{~Hz}), 3.09(\mathrm{t}$, $4 \mathrm{H}, J=6.2 \mathrm{~Hz}), 2.65(\mathrm{~m}, 2 \mathrm{H}), 2.60(\mathrm{~s}, 2 \mathrm{H}), 1.70(\mathrm{~s}, \mathrm{br}, 2 \mathrm{H}), 0.70-1.10(\mathrm{~m}, 6 \mathrm{H}), 0.45-0.65(\mathrm{~m}$, 2H); ${ }^{13} \mathrm{C}$ NMR (DMSO-d 6 , $\left.75 \mathrm{MHz}\right) \oint 152.5,115.2,70.8,68.1,65.9,29.9,25.2$; HRMS (FAB) calcd for $\mathrm{C}_{16} \mathrm{H}_{27} \mathrm{O}_{6}\left(\mathrm{M}+\mathrm{H}^{+}\right)$315.1808, found 315.1808.

\section{Determination of overall S/R ratio of 12-tetra-(R)-MTPA ester}

The overall S/R ratio of $\mathbf{1 2}$ was determined by conversion to the tetra-Mosher ester derivative.

For the desired (S,S) diastereomer, 12-tetra-(R)-MTPA ester: ${ }^{1} \mathrm{H}$ NMR $\left(\mathrm{CDCl}_{3}, 400 \mathrm{MHz}\right) \oint$ 7.20-7.55 (m, 20H), $6.77(\mathrm{~s}, 4 \mathrm{H}), 5.43(\mathrm{~m}, 2 \mathrm{H}), 4.61(\mathrm{dd}, \mathrm{J}=2.8,12.0 \mathrm{~Hz}, 2 \mathrm{H}), 4.32(\mathrm{dd}, \mathrm{J}=$ 4.8, $12.0 \mathrm{~Hz}, 2 \mathrm{H}), 3.86(\mathrm{~m}, 4 \mathrm{H}), 3.44(\mathrm{~s}, 6 \mathrm{H}), 3.43(\mathrm{~s}, 6 \mathrm{H}), 1.88(\mathrm{~m}, 4 \mathrm{H}), 1.78(\mathrm{~m}, 4 \mathrm{H}) .{ }^{13} \mathrm{C} \mathrm{NMR}$ $\left(\mathrm{CDCl}_{3}, 75 \mathrm{MHz}\right) \oint 166.4,166.2,153.3,132.2,132.0,129.8,128.6,127.6,127.5,115.8,85.2$, $84.8,73.8,68.0,66.0,55.7,55.5,27.7,25.3$.

The tetraol mixture obtained from the reaction of $\mathbf{1 1}$ with osmium tetraoxide was converted to the corresponding mixture of tetra-R-MTPA ester diastereomers, and the ${ }^{1} \mathrm{HNMR}$ data for this sample was compared to that for 12-tetra-(R)-MTPA ester.

One of the methylene protons attached to the carbinol carbon of the primary alcohol-MTPA residue resonated at a distinct chemical shift depending on the absolute configuration at the adjacent secondary alcohol. These signals occurred as dd's at $\delta 4.61$ and 4.69 respectively for S and $\mathrm{R}$ configurations at the secondary alcohol. (The chemical shifts for the corresponding protons in the "pseudo"-meso diastereomer $(\mathrm{S} / \mathrm{R})$ were identical to the shifts in the R/R or $\mathrm{S} / \mathrm{S}$ diastereomers). The overall $\mathrm{S} / \mathrm{R}$ ratio was determined by integration of these signals. 


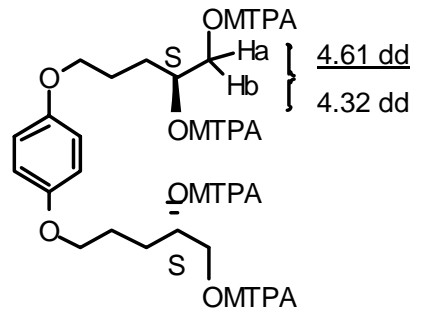

(S,S)-12- tetra-(R)-MTPA

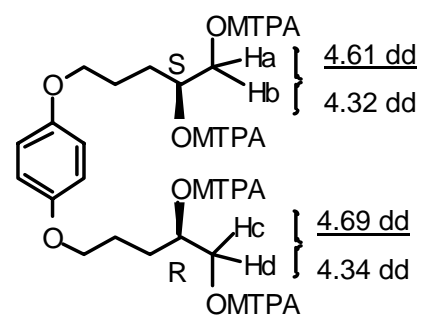

(S,R)-12-tetra-(R)-MTPA<smiles>[Y]C(=O)[C@](OC)(c1ccccc1)C(F)(F)C(F)(F)F</smiles>

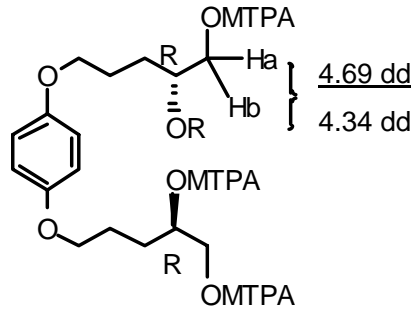

(R,R)-12-tetra-(R)-MTPA

Stereoisomer enrichment through repeated recrystallization of $\mathbf{1 2}$

\begin{tabular}{lll} 
no. of recrystallizations & S:R & Yield \% \\
\hline crude 12 & not determined & 99 \\
2 & $10: 1$ & 74 \\
3 & $20: 1$ & 65
\end{tabular}

\section{Bis-silyl ether 13}

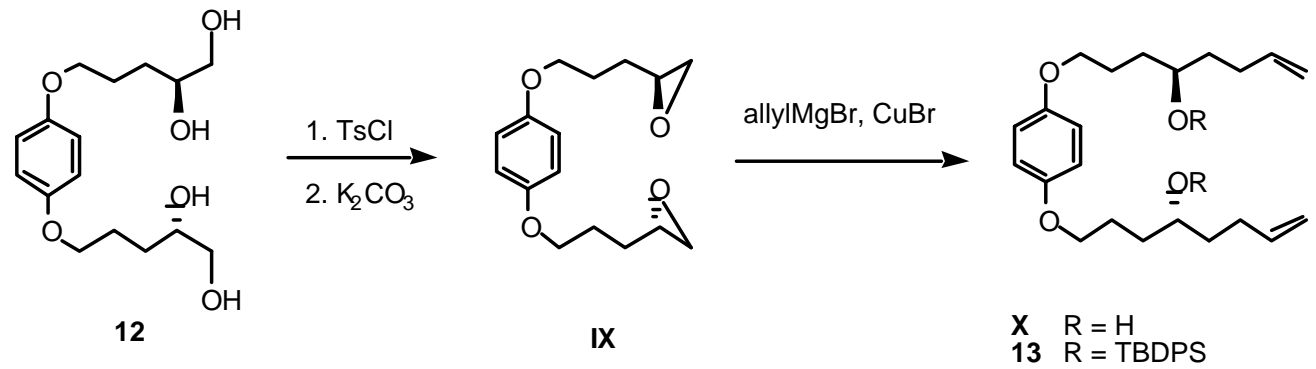

\section{Bis-epoxide IX}

To a solution of compound $12(7.11 \mathrm{~g}, 23 \mathrm{mmol})$ in pyridine $(100 \mathrm{~mL})$ was added p-toluenesulfonyl chloride $(9.6 \mathrm{~g}, 50.35 \mathrm{mmol})$. The solution was stirred for $4 \mathrm{~h}$ at $\mathrm{rt}$, then quenched by adding $\mathrm{MeOH}(3 \mathrm{~mL})$. The mixture was washed with saturated aqueous $\mathrm{Na}_{2} \mathrm{CO}_{3}$, 
and extracted with $\mathrm{CH}_{2} \mathrm{Cl}_{2}(3 \times 100 \mathrm{~mL})$. The organic layer was dried $\left(\mathrm{Na}_{2} \mathrm{SO}_{4}\right)$, filtered, and the filtrate evaporated in vacuo. The residue was dissolved in $\mathrm{MeOH}(120 \mathrm{~mL})$, and $\mathrm{K}_{2} \mathrm{CO}_{3}(39 \mathrm{~g}$, $0.37 \mathrm{~mol}$ ) was added to the vigorously stirred solution. After $3 \mathrm{~h}$ at $\mathrm{rt}$, the mixture was poured into water $(200 \mathrm{~mL})$ and extracted with $\mathrm{CH}_{2} \mathrm{Cl}_{2}(3 \times 150 \mathrm{~mL})$. The combined organic phase was dried $\left(\mathrm{Na}_{2} \mathrm{SO}_{4}\right)$ and concentrated. The residue was purified by FCC to afford $\mathbf{I X}(5.24 \mathrm{~g}, 84 \% 2$ steps): $\mathrm{R}_{\mathrm{f}}=0.77$ (50\% EtOAc: petroleum ether); ${ }^{1} \mathrm{H} \mathrm{NMR}\left(\mathrm{CDCl}_{3}, 500 \mathrm{MHz}\right) \delta 6.80(\mathrm{~s}, 4 \mathrm{H})$, $3.95(\mathrm{~m}, 4 \mathrm{H}), 2.95(\mathrm{~m}, 2 \mathrm{H}), 2.75(\mathrm{t}, 2 \mathrm{H}, J=4.03 \mathrm{~Hz}), 2.50(\mathrm{~m}, 2 \mathrm{H}), 1.50-2.00(\mathrm{~m}, 8 \mathrm{H}) ;{ }^{13} \mathrm{C}$ NMR $\left(\mathrm{CDCl}_{3}, 75 \mathrm{MHz}\right) \delta$ 153.4, 115.0, 68.4, 52.3, 47.3, 29.5, 26.3; HRMS (FAB) calcd for $\mathrm{C}_{16} \mathrm{H}_{22} \mathrm{O}_{4}$ 278.1518 , found 278.1519 .

\section{Diol X}

Allylmagnesium bromide $(1.0 \mathrm{M}$ in ether, $182.5 \mathrm{~mL})$ was added dropwise to a suspension of $\mathrm{CuBr}(1.6 \mathrm{~g}, 11.1 \mathrm{mmol})$ in anhydrous THF $(100 \mathrm{~mL})$ at $0{ }^{\circ} \mathrm{C}$. A solution of $\mathbf{I X}(5 \mathrm{~g}, 18 \mathrm{mmol})$ in anhydrous THF $(60 \mathrm{~mL})$ was then introduced at $0{ }^{\circ} \mathrm{C}$, and the reaction mixture was stirred for $2 \mathrm{~h}$ at this temperature. At this time the mixture was poured into saturated aqueous $\mathrm{NH}_{4} \mathrm{Cl}$ and the mixture extracted with diethyl ether. The organic phase was dried $\left(\mathrm{Na}_{2} \mathrm{SO}_{4}\right)$, filtered, and the filtrate evaporated in vacuo. The residue was purified by FCC (silica gel, 40\% EtOAc: petroleum ether) to afford $\mathrm{X}(4.6 \mathrm{~g}, 72 \%): \mathrm{R}_{\mathrm{f}}=0.50$ (40\% EtOAc:60\% petroleum ether); ${ }^{1} \mathrm{H} \mathrm{NMR}\left(\mathrm{CDCl}_{3}\right.$, $500 \mathrm{MHz}) \delta 6.80(\mathrm{~s}, 4 \mathrm{H}), 5.80(\mathrm{~m}, 2 \mathrm{H}), 4.90-5.10(\mathrm{~m}, 4 \mathrm{H}), 3.90(\mathrm{t}, 4 \mathrm{H}, J=6.5 \mathrm{~Hz}), 3.65(\mathrm{~m}, 2 \mathrm{H})$,

2.00-2.30 (m, 6H), 1.50-2.00 (m, 12H); ${ }^{13} \mathrm{C} \mathrm{NMR}\left(\mathrm{CDCl}_{3}, 75 \mathrm{MHz}\right) \delta 153.2,138.6,115.7,115.0$, 71.3, 68.9, 36.9, 34.5, 30.4, 26.0; HRMS (FAB) calcd for $\mathrm{C}_{22} \mathrm{H}_{35} \mathrm{O}_{4}\left(\mathrm{M}+\mathrm{H}^{+}\right)$363.2535, found 363.2537 .

\section{Bis-silyl ether 13}

A mixture of diol X (4.6g, $12.85 \mathrm{mmol})$, tert-butyldiphenylsilychloride (14 g, $51.4 \mathrm{mmol})$, imidazole (4.4 g, $64.7 \mathrm{mmol}), 4-(\mathrm{N}, \mathrm{N}$-dimethylamino)pyridine $(2 \mathrm{~g}, 16.7 \mathrm{mmol})$ in anhydrous THF $(100 \mathrm{~mL})$ was stirred under argon at $40{ }^{\circ} \mathrm{C}$ for $2 \mathrm{~d}$. The mixture was quenched with brine and 
extracted with ether $(3 \times 150 \mathrm{~mL})$. The combined organic extract was dried $\left(\mathrm{Na}_{2} \mathrm{SO}_{4}\right)$, filtered, and concentrated. The residue was purified by FCC to afford $13(10.7 \mathrm{~g}, 99 \%): \mathrm{R}_{\mathrm{f}}=0.26$ (petroleum ether); ${ }^{1} \mathrm{H} \mathrm{NMR}\left(\mathrm{CDCl}_{3}, 500 \mathrm{MHz}\right) \delta$ 7.7-7.8 (m, 8H), 7.3-7.5 (m, 12H), $6.8(\mathrm{~s}, 4 \mathrm{H})$, 5.6-5.8 (m, 2H), 4.9-5.0 (m, 4H), $3.9(\mathrm{t}, 4 \mathrm{H}, J=5.5 \mathrm{~Hz}), 3.7-3.8(\mathrm{~m}, 2 \mathrm{H}), 2.0-2.1(\mathrm{~m}, 4 \mathrm{H})$, 1.6-1.9 (m, 12H), 1.05 (s, 18H); ${ }^{13} \mathrm{C} \mathrm{NMR}\left(\mathrm{CDCl}_{3}, 75 \mathrm{MHz}\right) \delta 153.2,138.7,136.1,135.7,134.6$, $129.7,127.7,127.4,115.6,114.5,72.6,68.8,35.8,32.8,29.6,27.4,25.1,19.7$.

\section{Alcohol 14 and Methyl ester 15}

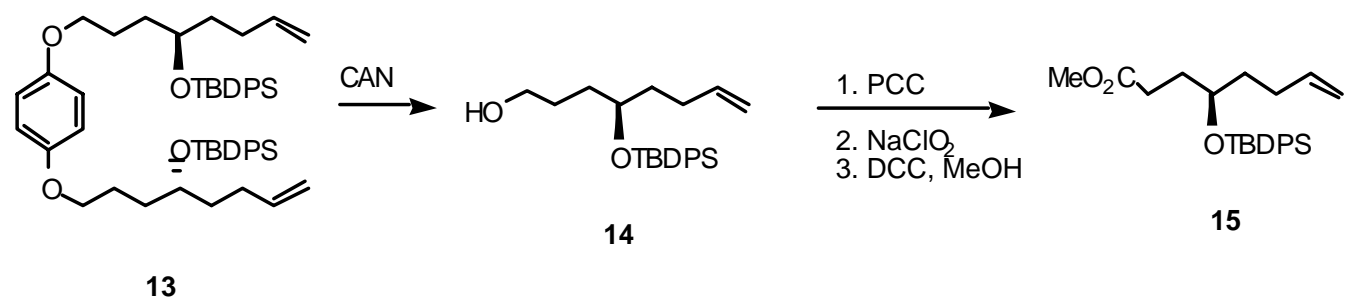

\section{Alcohol 14}

To an ice cooled solution of $13(10.7 \mathrm{~g}, 12.8 \mathrm{mmol})$ in $240 \mathrm{~mL}$ of acetonitrile-water (5:1) was added CAN in one portion. After 15 min the mixture was partitioned between ethyl acetate and brine. The organic layer was washed with a saturated aqueous $\mathrm{NaHCO}_{3}$ and brine, dried $\left(\mathrm{Na}_{2} \mathrm{SO}_{4}\right)$, filtered, and concentrated. $\mathrm{FCC}$ of the residue (25\% EtOAc: petroleum ether) afforded alcohol 14 (7.8 g, 80\%): $\mathrm{R}_{\mathrm{f}}=0.56$ (25\% EtOAc: petroleum ether); ${ }^{1} \mathrm{H} \mathrm{NMR}\left(\mathrm{CDCl}_{3}, 300 \mathrm{MHz}\right) \oint$ 7.6-7.7 (d, 4H, $J=7.0 \mathrm{~Hz}), 7.3-7.5(\mathrm{~m}, 6 \mathrm{H}), 5.5-5.7(\mathrm{~m}, 1 \mathrm{H}), 4.8-4.9(\mathrm{~m}, 2 \mathrm{H}), 3.8(\mathrm{t}, 1 \mathrm{H}, J=5.1$

$\mathrm{Hz}), 3.4-3.5(\mathrm{t}, 2 \mathrm{H}, J=5.5 \mathrm{~Hz}), 1.9-2.1(\mathrm{~m}, 2 \mathrm{H}), 1.5-1.7(\mathrm{~m}, 6 \mathrm{H}), 1.05(\mathrm{~s}, 9 \mathrm{H}) ;{ }^{13} \mathrm{C} \mathrm{NMR}\left(\mathrm{CDCl}_{3}\right.$, $75 \mathrm{MHz}) \oint 138.68,136.07,134.50,129.71,127.64,114.45,72.67,63.21,35.54,32.55,29.61$, 28.20, 27.39, 19.70; HRMS (FAB) calcd for $\mathrm{C}_{24} \mathrm{H}_{35} \mathrm{O}_{2} \mathrm{Si}\left(\mathrm{M}+\mathrm{H}^{+}\right)$383.2406, found 383.2407.

\section{Methyl ester 15}

To a suspension of freshly activated powdered 4A molecular sieves $(10.7 \mathrm{~g})$, celite $(10.7 \mathrm{~g})$, florisil $(10.7 \mathrm{~g})$, sodium acetate $(4.1 \mathrm{~g}, 50 \mathrm{mmol})$ and pyridinium chlorochromate $(10.7 \mathrm{~g}, 50$ $\mathrm{mmol})$ in $\mathrm{CH}_{2} \mathrm{Cl}_{2}(150 \mathrm{~mL})$ was added alcohol $14(7.77 \mathrm{~g}, 20 \mathrm{mmol})$. The mixture was stirred for 
$2 \mathrm{~h}$, and then filtered through a short column of silica gel. The filtrate was evaporated in vacuo. The residue was dissolved in a mixture of $\mathrm{NaH}_{2} \mathrm{PO}_{4} \cdot \mathrm{H}_{2} \mathrm{O}(27 \mathrm{~g}, 0.2 \mathrm{~mol})$ and $\mathrm{CH}_{3} \mathrm{CN}-\mathrm{H}_{2} \mathrm{O}(150$ mL-30 mL) and the suspension cooled to $0-5{ }^{\circ} \mathrm{C} .30 \%$ aqueous $\mathrm{H}_{2} \mathrm{O}_{2}(2.3 \mathrm{~mL}, 24 \mathrm{mmol})$ and a solution of $\mathrm{NaClO}_{2}(80 \%, 2.7 \mathrm{~g}, 24 \mathrm{mmol})$ in water $(130 \mathrm{~mL})$ were then successively added, the mixture warmed to $\mathrm{rt}$ and stirred at this temperature for $1 \mathrm{~h}$. The reaction was quenched by addition of $\mathrm{Na}_{2} \mathrm{SO}_{3}(5.5 \mathrm{~g})$, and extracted with EtOAc $(3 \times 100 \mathrm{~mL})$. The organic extract was washed with water and brine, dried $\left(\mathrm{Na}_{2} \mathrm{SO}_{4}\right)$, filtered, and concentrated. $\mathrm{FCC}$ of the residue afforded the acid derivative $(5.8 \mathrm{~g}, 72 \%): \mathrm{R}_{\mathrm{f}}=0.60\left(20 \%\right.$ EtOAc: petroleum ether); ${ }^{1} \mathrm{H}$ NMR $\left(\mathrm{CDCl}_{3}, 300 \mathrm{MHz}\right) \delta$ 7.6-7.7 (d, 4H, $\left.J=7.0 \mathrm{~Hz}\right), 7.3-7.5(\mathrm{~m}, 6 \mathrm{H})$, 5.5-5.7 (m, 1H), 4.8-4.9 (m, 2H), $3.8(\mathrm{t}, 1 \mathrm{H}, J=5.5 \mathrm{~Hz}), 2.4(\mathrm{t}, 2 \mathrm{H}, J=7.0 \mathrm{~Hz}), 1.9-2.0(\mathrm{~m}, 2 \mathrm{H}), 1.7-1.9(\mathrm{~m}, 2 \mathrm{H}), 1.5-1.6(\mathrm{dd}$, $2 \mathrm{H}, J=13.5 \mathrm{~Hz}), 1.05(\mathrm{~s}, 9 \mathrm{H}) ;{ }^{13} \mathrm{C} \mathrm{NMR}\left(\mathrm{CDCl}_{3}, 75 \mathrm{MHz}\right) \oint 180.1,138.3,136.0,134.4,134.1$, $129.8,129.7,127.7,127.7,114.6,71.9,35.7,31.0,29.8,29.5,27.4,19.7$.

To a solution of the acid obtained from the previous step $(5.7 \mathrm{~g}, 14.4 \mathrm{mmol})$ in anhydrous methanol (100 mL) were added 4-N,N-dimethylaminopyridine (176 mg, $1.4 \mathrm{mmol})$ and dicyclohexylcarbodiimide $(4.45 \mathrm{~g}, 21.6 \mathrm{mmol})$. The solution was stirred for $1 \mathrm{~h} \mathrm{at} \mathrm{rt}$, then diluted with ether and the resulting suspension filtered through a pad of celite. The filtrate was dried $\left(\mathrm{Na}_{2} \mathrm{SO}_{4}\right)$, filtered, and concentrated. FCC of the residue afforded methyl ester $15^{7}$ (5.2 $\left.\mathrm{g}, 88 \%\right)$ : $\mathrm{R}_{\mathrm{f}}=0.90$ (15\% EtOAc: petroleum ether); $[\alpha]^{22}{ }_{\mathrm{D}}-4.38$ (c 1.54, $\left.\mathrm{CHCl}_{3}\right) ;{ }^{1} \mathrm{H} \mathrm{NMR}\left(\mathrm{CDCl}_{3}, 300\right.$ $\mathrm{MHz}) \oint 7.7-7.8(\mathrm{~d}, 4 \mathrm{H}, J=6.6 \mathrm{~Hz}), 7.3-7.5(\mathrm{~m}, 6 \mathrm{H}), 5.5-5.7(\mathrm{~m}, 1 \mathrm{H}), 4.8-5.0(\mathrm{~m}, 2 \mathrm{H}), 3.8(\mathrm{t}, 1 \mathrm{H}$, $J=5.5 \mathrm{~Hz}), 3.65(\mathrm{~s}, 3 \mathrm{H}), 2.4(\mathrm{t}, 2 \mathrm{H}, J=7.7 \mathrm{~Hz}), 1.9-2.0(\mathrm{~m}, 2 \mathrm{H}), 1.7-1.9(\mathrm{~m}, 2 \mathrm{H}), 1.5-1.6(\mathrm{dd}$, $2 \mathrm{H}, J=13.5 \mathrm{~Hz}), 1.05(\mathrm{~s}, 9 \mathrm{H}) ;{ }^{13} \mathrm{C} \mathrm{NMR}\left(\mathrm{CDCl}_{3}, 75 \mathrm{MHz}\right) \delta .174 .5,138.8,136.6,135.1,134.8$, 130.3, 128.2, 115.1, 72.7, 52.1, 36.3, 31.9, 30.4, 30.0, 27.9, 20.2; LRMS (FAB) 411.2 (M + $\left.\mathrm{H}^{+}\right)$. 


\section{Physical data for Butenolide $2^{7}$.}

$\mathrm{R}_{\mathrm{f}}=0.80\left(70 \%\right.$ EtOAc: petroleum ether); $[\alpha]^{22}{ }_{\mathrm{D}} 6.10$ (c 1.82, $\left.\mathrm{CHCl}_{3}\right) ;{ }^{1} \mathrm{H} \mathrm{NMR}\left(\mathrm{CDCl}_{3}, 500\right.$ MHz) $\oint 9.58(\mathrm{~s}, 1 \mathrm{H}), 7.65(\mathrm{~m}, 4 \mathrm{H}), 7.3-7.5(\mathrm{~m}, 6 \mathrm{H}), 6.89(\mathrm{~s}, 1 \mathrm{H}), 4.89(\mathrm{~m}, 1 \mathrm{H}), 4.07(\mathrm{~m}, 1 \mathrm{H})$, 2.4-2.6 (m, 4H), 1.6-1.9 (m, 2H), $1.32(\mathrm{~d}, 3 \mathrm{H}, J=7.0 \mathrm{~Hz}), 1.05(\mathrm{~s}, 9 \mathrm{H}) ;{ }^{13} \mathrm{C}$ NMR $\left(\mathrm{CDCl}_{3}, 75\right.$ MHz) $\delta 202.5,173.7,151.7,135.9,133.8,133.7,130.2,130.1,130.0,127.9,127.8,77.5,71.0$, 39.5, 32.2, 28.4, 27.3, 19.6, 19.2. HRMS (ESI) calcd for $\mathrm{C}_{26} \mathrm{H}_{32} \mathrm{O}_{4} \mathrm{Si}\left(\mathrm{M}+\mathrm{H}^{+}\right) 459.1968$, found 459.1965 . 
Comparison of ${ }^{13} \mathrm{CNMR}$ of Bullatanocin (Squamostatin-C) and synthetic material ${ }^{13} \mathrm{C}$ NMR in $\mathrm{CDCl}_{3}$ (Natural compound: $125 \mathrm{MHz}$; synthetic compound: $100 \mathrm{MHz}$; rel to $\mathrm{CDCl}_{3}$ at 77.00 ppm, carbon assignments made by comparison to literature values)

\begin{tabular}{|c|c|c|c|c|c|}
\hline Carbon \# & $\begin{array}{l}\text { Squamostation-C } \\
\text { ref. } 5 \mathrm{~b}\end{array}$ & $\begin{array}{l}\text { Bullatanocin } \\
\text { ref. } 5 \mathrm{~b}\end{array}$ & Synthetic Compound (77.00) & Syn-Squ & Bul-Syn \\
\hline 1 & 174.6 & 174.44 & 174.64 & 0.04 & 0.20 \\
\hline 2 & 131.2 & 130.95 & 131.18 & -0.02 & 0.23 \\
\hline 3 & 33.4 & $37.31-25.52 *$ & 33.35 & -0.05 & - \\
\hline 4 & 70.0 & 69.74 & 69.96 & -0.04 & 0.22 \\
\hline 5 & 37.4 & $37.31-25.52 *$ & 37.38 & -0.02 & - \\
\hline 6 & 25.5 & $37.31-25.52 *$ & 25.52 & 0.02 & - \\
\hline $7-9$ & $29-30^{*}$ & $37.31-25.52 *$ & 29.93 & - & - \\
\hline 10 & 26.1 & $37.31-25.52 *$ & 26.13 & 0.03 & - \\
\hline 11 & 35.6 & $37.31-25.52 *$ & 35.55 & -0.05 & - \\
\hline 12 & 79.3 & 79.21 & 79.29 & -0.01 & 0.08 \\
\hline 13 & 32.4 & $37.31-25.52 *$ & 32.39 & -0.01 & - \\
\hline 14 & 28.4 & $37.31-25.52 *$ & 28.39 & -0.01 & - \\
\hline 15 & 82.0 & 81.97 & 81.98 & -0.02 & 0.01 \\
\hline 16 & 74.4 & 74.33 & 74.41 & 0.01 & 0.08 \\
\hline 17 & $29-30^{*}$ & $37.31-25.52 *$ & 29.70 & - & - \\
\hline 18 & $29-30^{*}$ & $37.31-25.52 *$ & 29.61 & - & - \\
\hline 19 & 74.3 & 74.21 & 74.25 & -0.05 & 0.04 \\
\hline 20 & 82.7 & 82.65 & 82.70 & 0.00 & 0.05 \\
\hline 21 & 28.7 & $37.31-25.52 *$ & 28.69 & -0.01 & - \\
\hline 22 & 28.7 & $37.31-25.52 *$ & 28.69 & -0.01 & - \\
\hline 23 & 82.7 & 82.67 & 82.70 & 0.00 & 0.03 \\
\hline 24 & 74.0 & 74.00 & 74.06 & 0.06 & 0.06 \\
\hline 25 & 33.5 & $37.31-25.52 *$ & 33.43 & -0.07 & - \\
\hline 26 & 25.6 & $37.31-25.52 *$ & 25.59 & -0.01 & - \\
\hline 27 & $29-30^{*}$ & $37.31-25.52 *$ & 29.61 & - & - \\
\hline 28 & $29-30 *$ & $37.31-25.52 *$ & 29.51 & - & - \\
\hline 29 & $29-30^{*}$ & $37.31-25.52 *$ & 29.40 & - & - \\
\hline 30 & $29-30^{*}$ & $37.31-25.52 *$ & 29.40 & - & - \\
\hline 31 & $29-30 *$ & $37.31-25.52 *$ & 29.32 & - & - \\
\hline 32 & 31.9 & $37.31-25.52 *$ & 31.90 & 0.00 & - \\
\hline 33 & 22.7 & 22.64 & 22.67 & -0.03 & 0.03 \\
\hline 34 & 14.1 & 14.10 & 14.11 & 0.01 & 0.01 \\
\hline 35 & 151.7 & 151.68 & 151.86 & 0.16 & 0.18 \\
\hline
\end{tabular}




\begin{tabular}{llllll} 
Carbon \# & Squamostation-C & Bullatanocin & Synthetic Compound (77.00) & Syn-Squ & Bul-Syn \\
\hline 36 & 77.9 & 77.88 & 77.97 & 0.07 & 0.09 \\
37 & 19.1 & 19.07 & 19.11 & 0.01 & 0.04
\end{tabular}

* exact ppm not listed in original literature: ref $5 \mathrm{a} / 5 \mathrm{~b}$.

Fig 1: ${ }^{13} \mathrm{CNMR}$ comparison for squamostatin $\mathrm{C}$ vs synthetic sample (comparisons are made with only those carbons for which exact chemical shifts are reported)

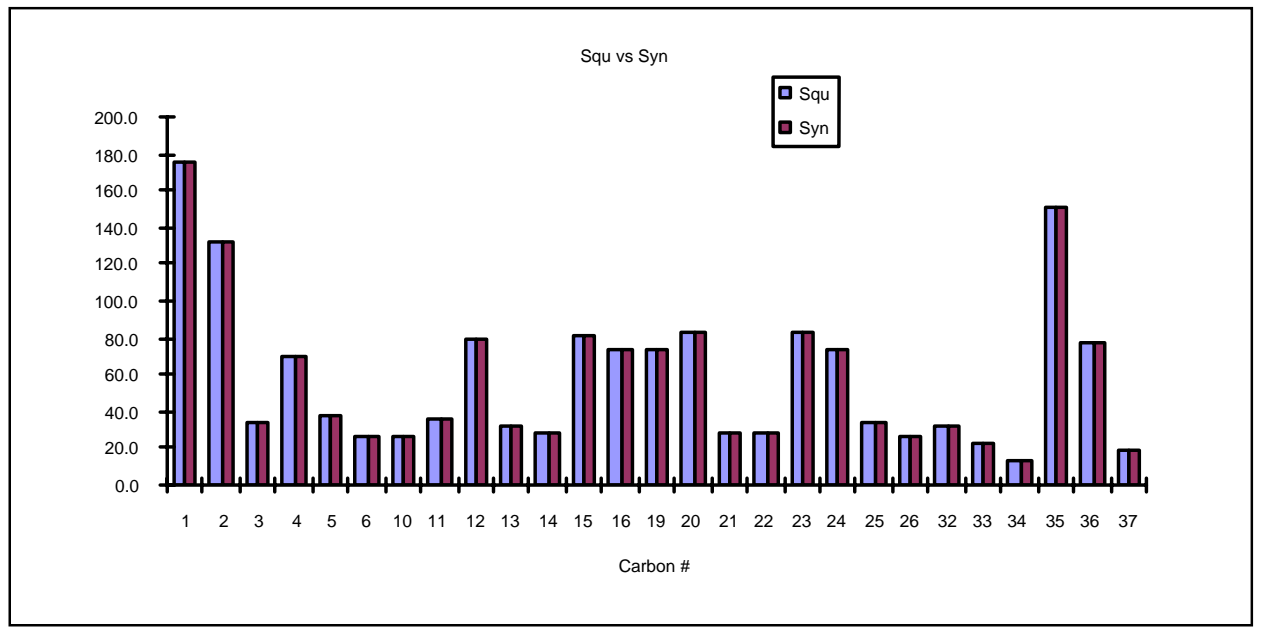

Fig 2: ${ }^{13} \mathrm{CNMR}$ comparison of carbinol carbons for squamostatin $\mathrm{C}$ vs synthetic sample

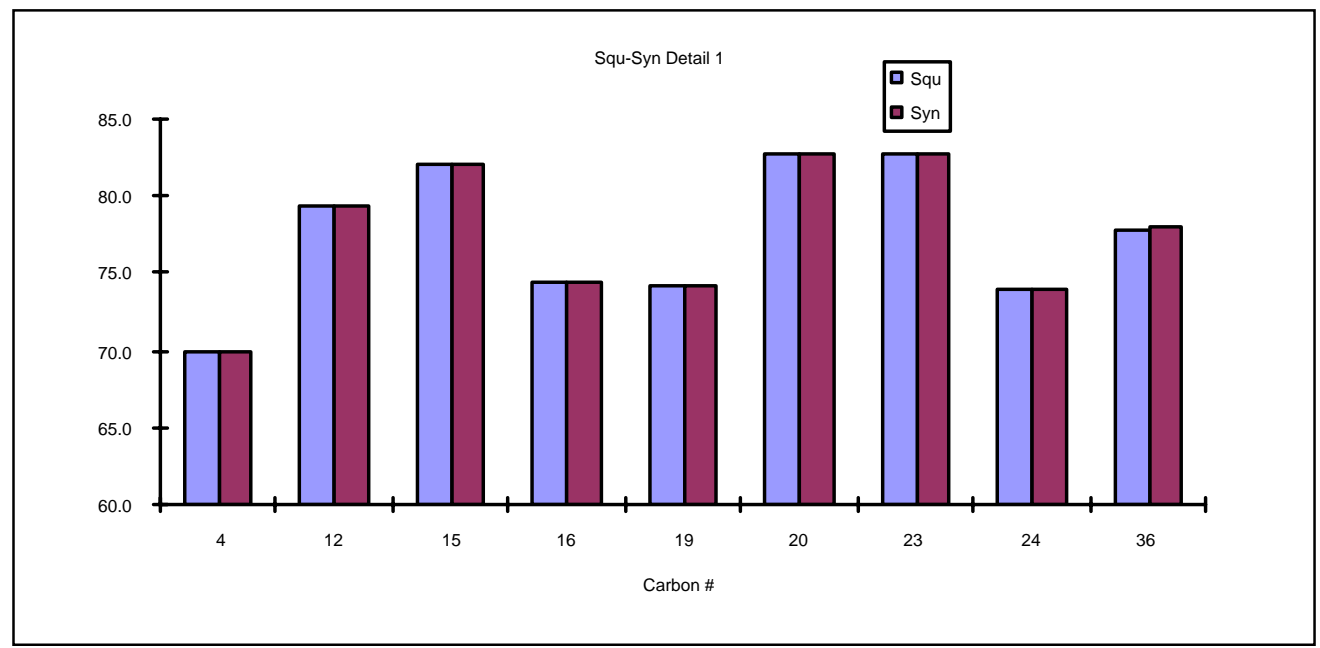


Fig 3: ${ }^{13} \mathrm{CNMR}$ comparison of 0-40 ppm region for squamostatin $\mathrm{C}$ vs synthetic sample (comparisons are made with only those carbons for which exact chemical shifts are reported)

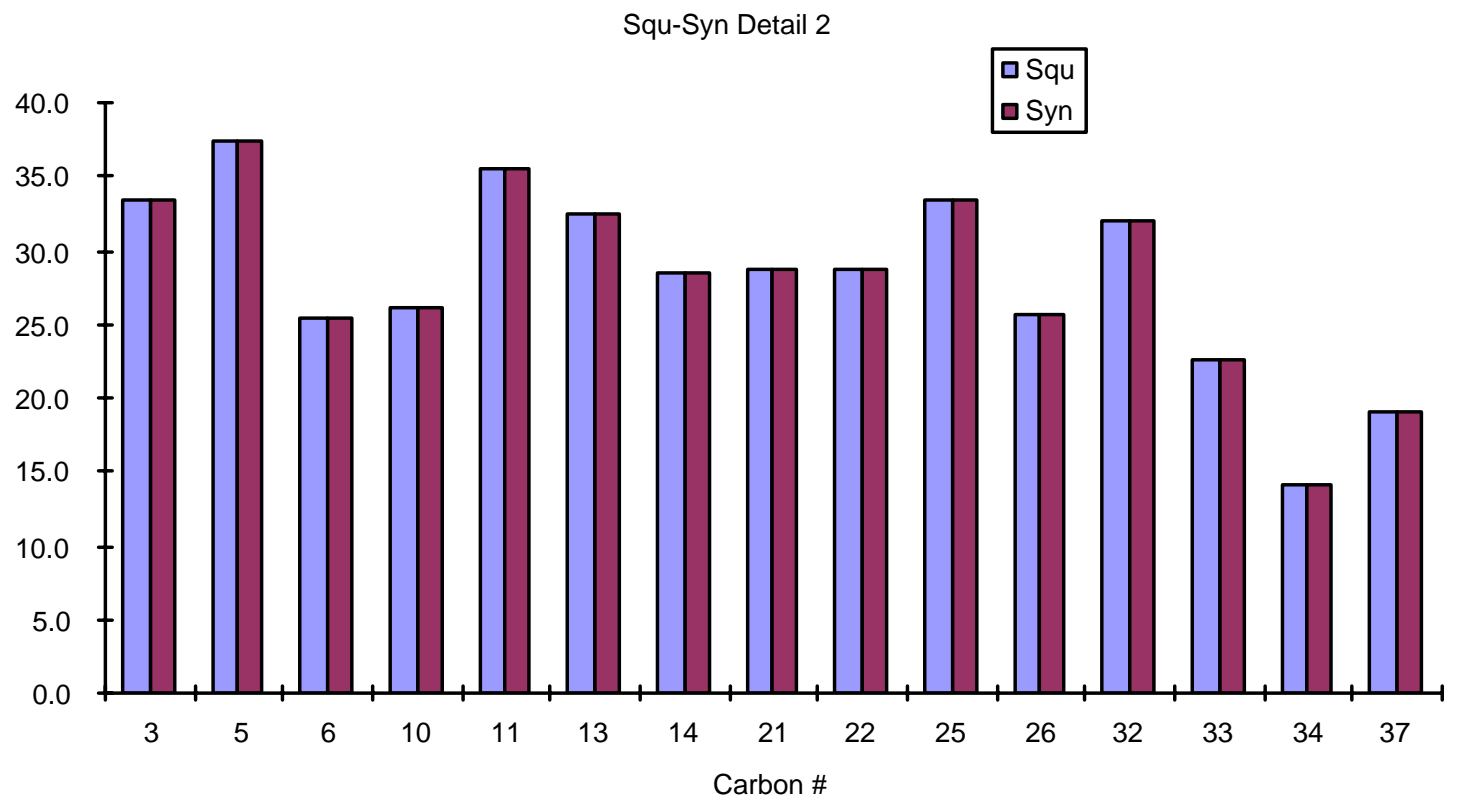

Fig 4: ${ }^{13}$ CNMR comparison for bullatanocin vs synthetic sample (comparisons are made with only those carbons for which exact chemical shifts are reported)

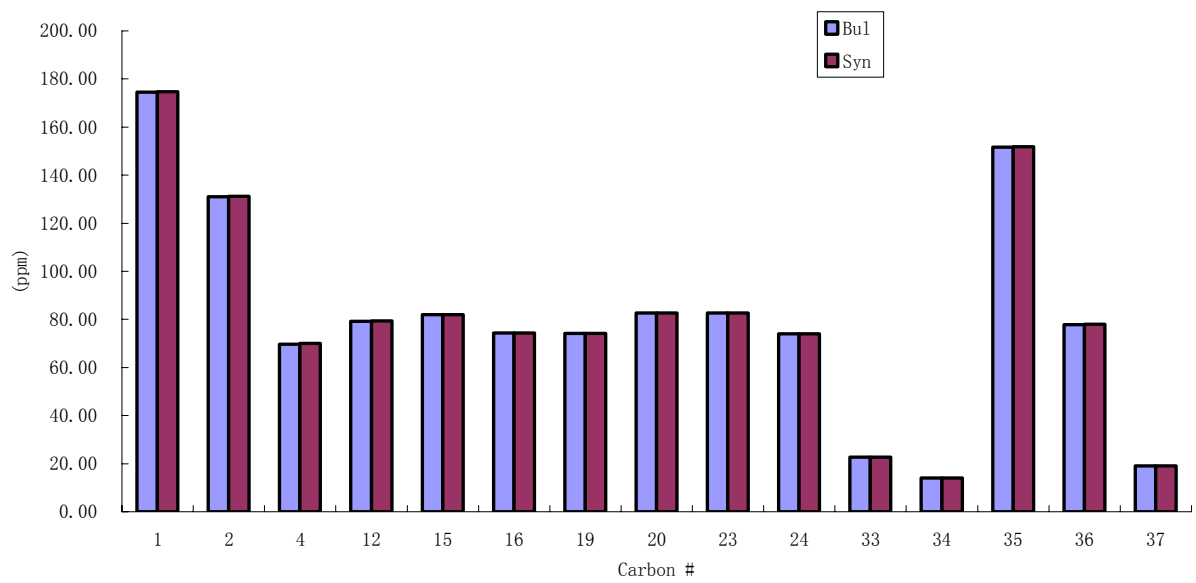


Fig 5: ${ }^{13}$ CNMR comparison of carbinol carbons for bullatanocin vs synthetic sample











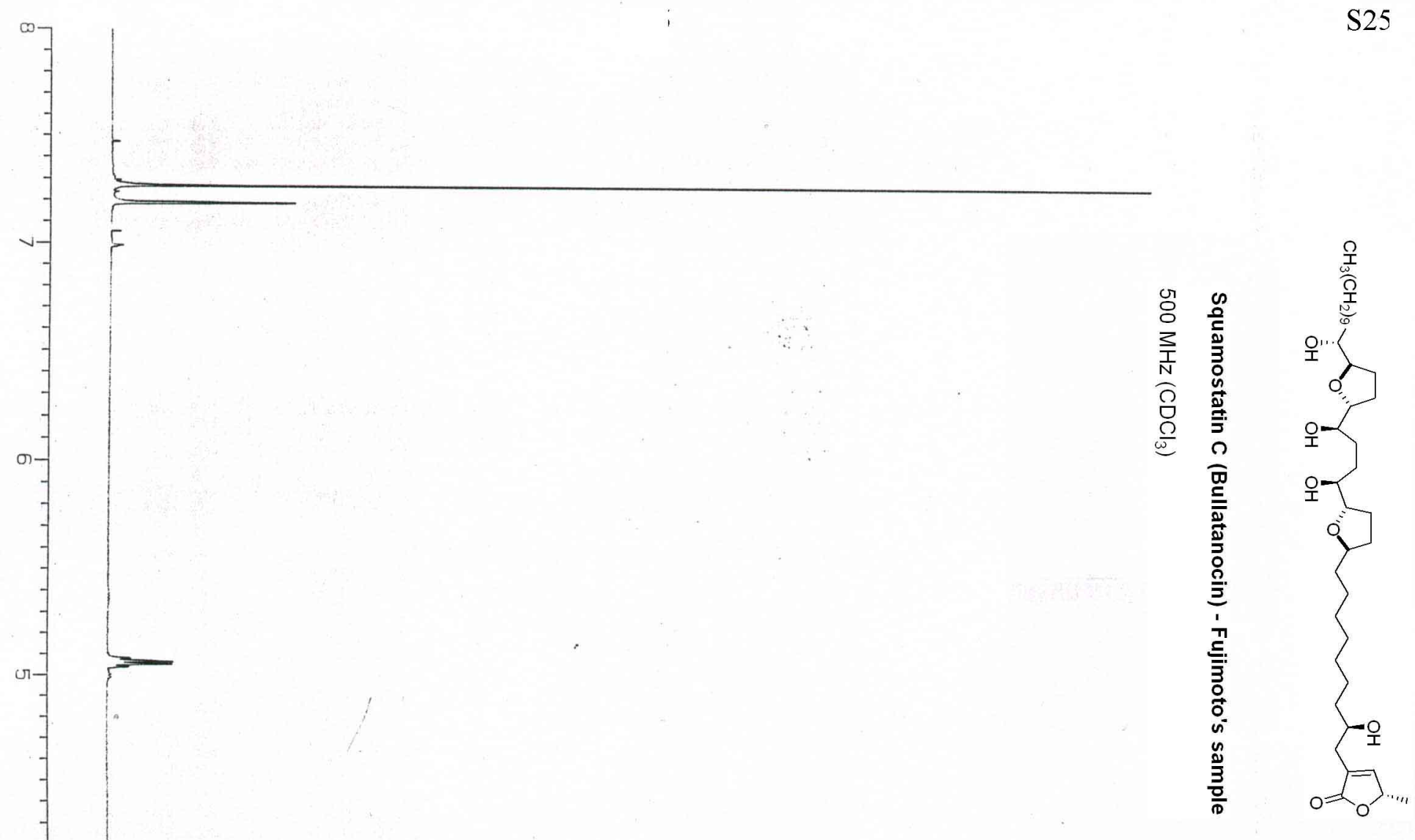




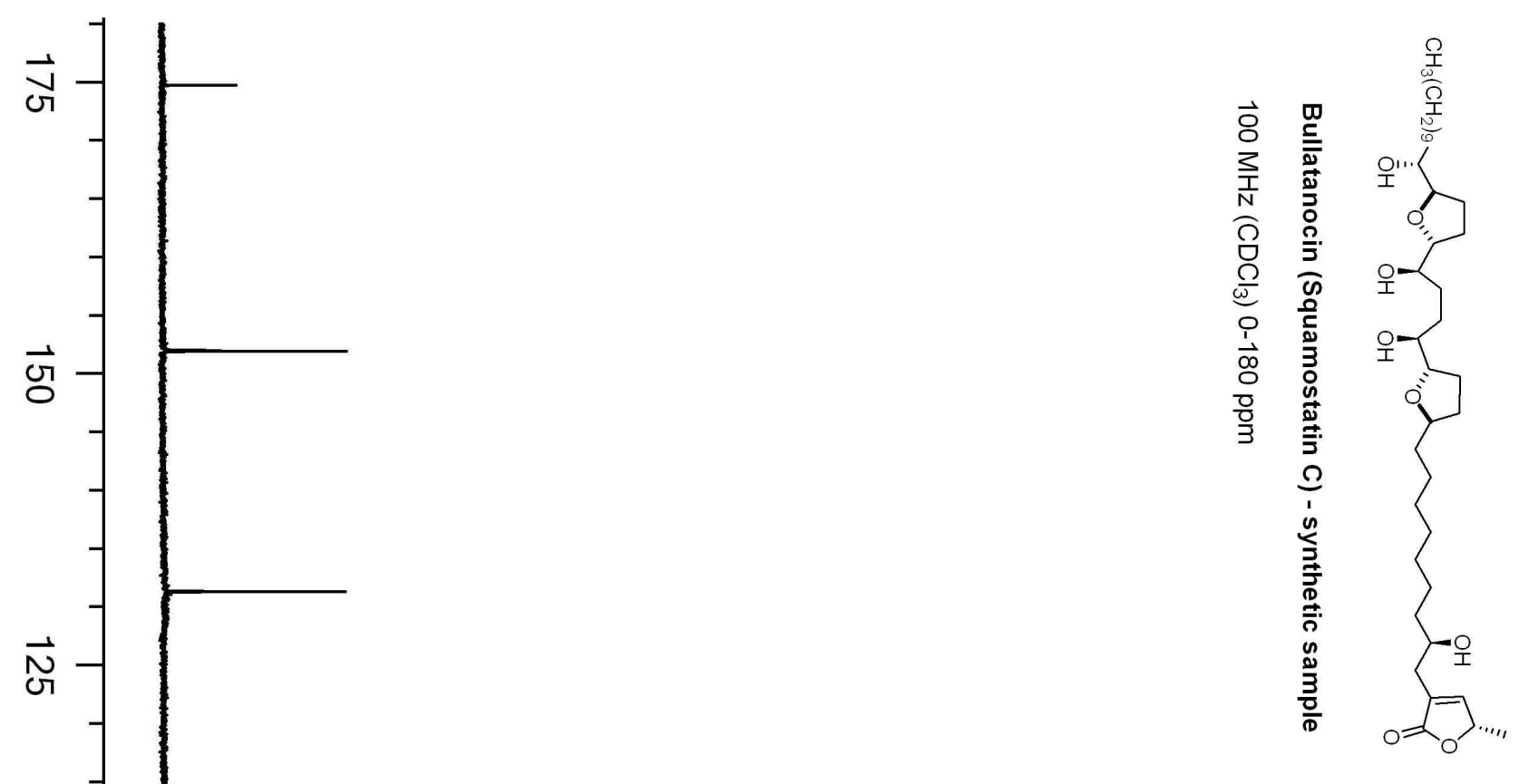



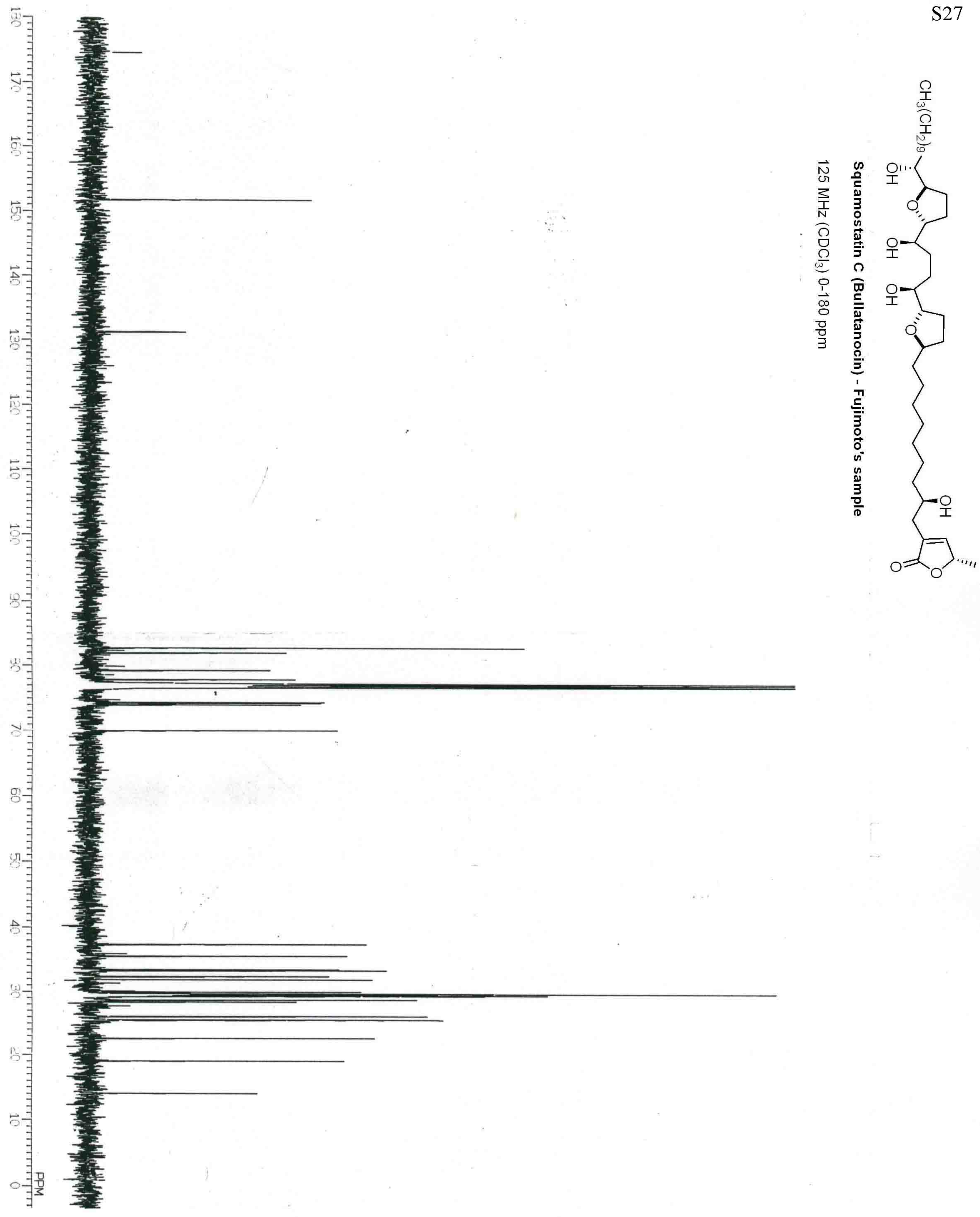


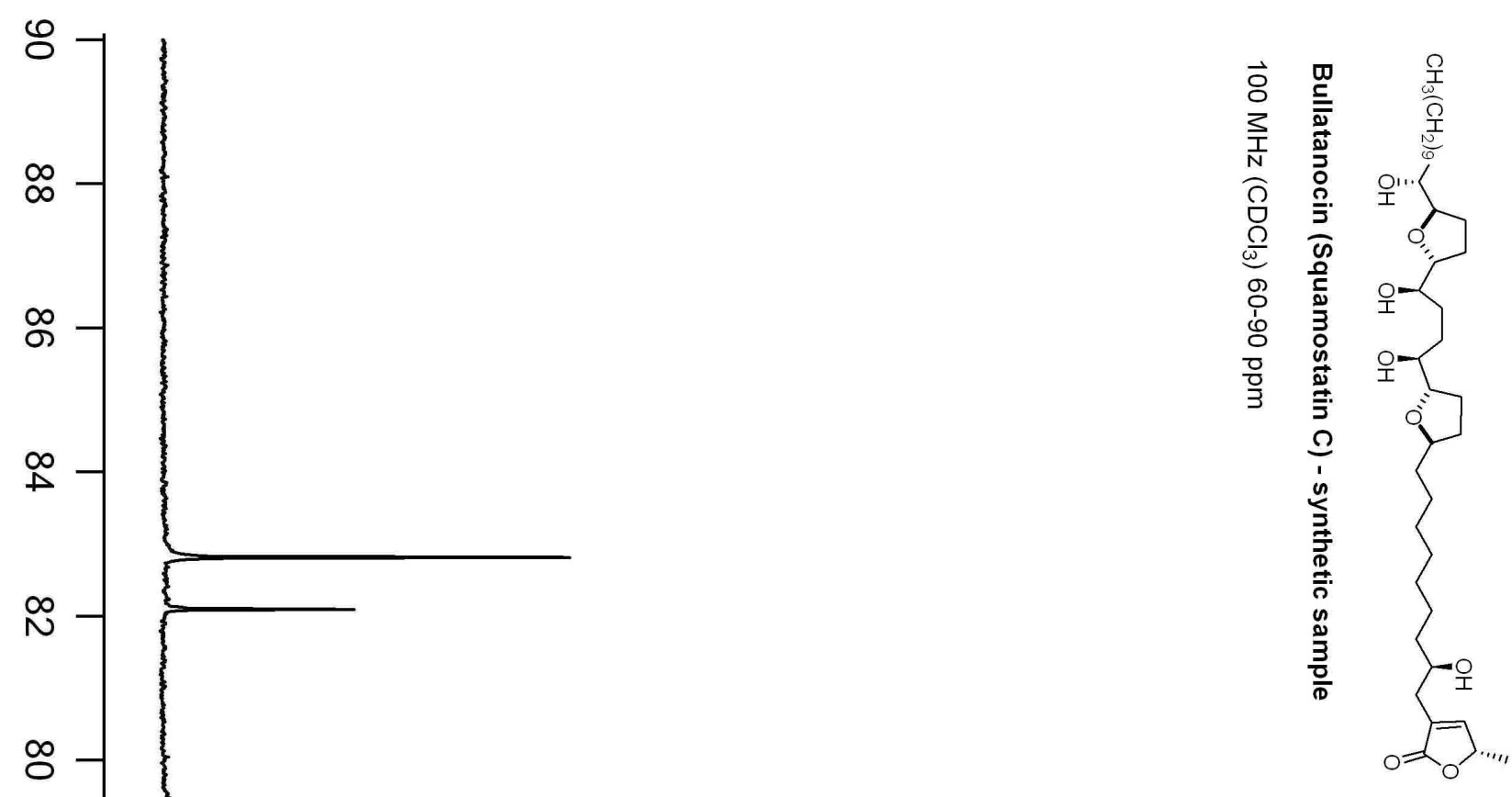



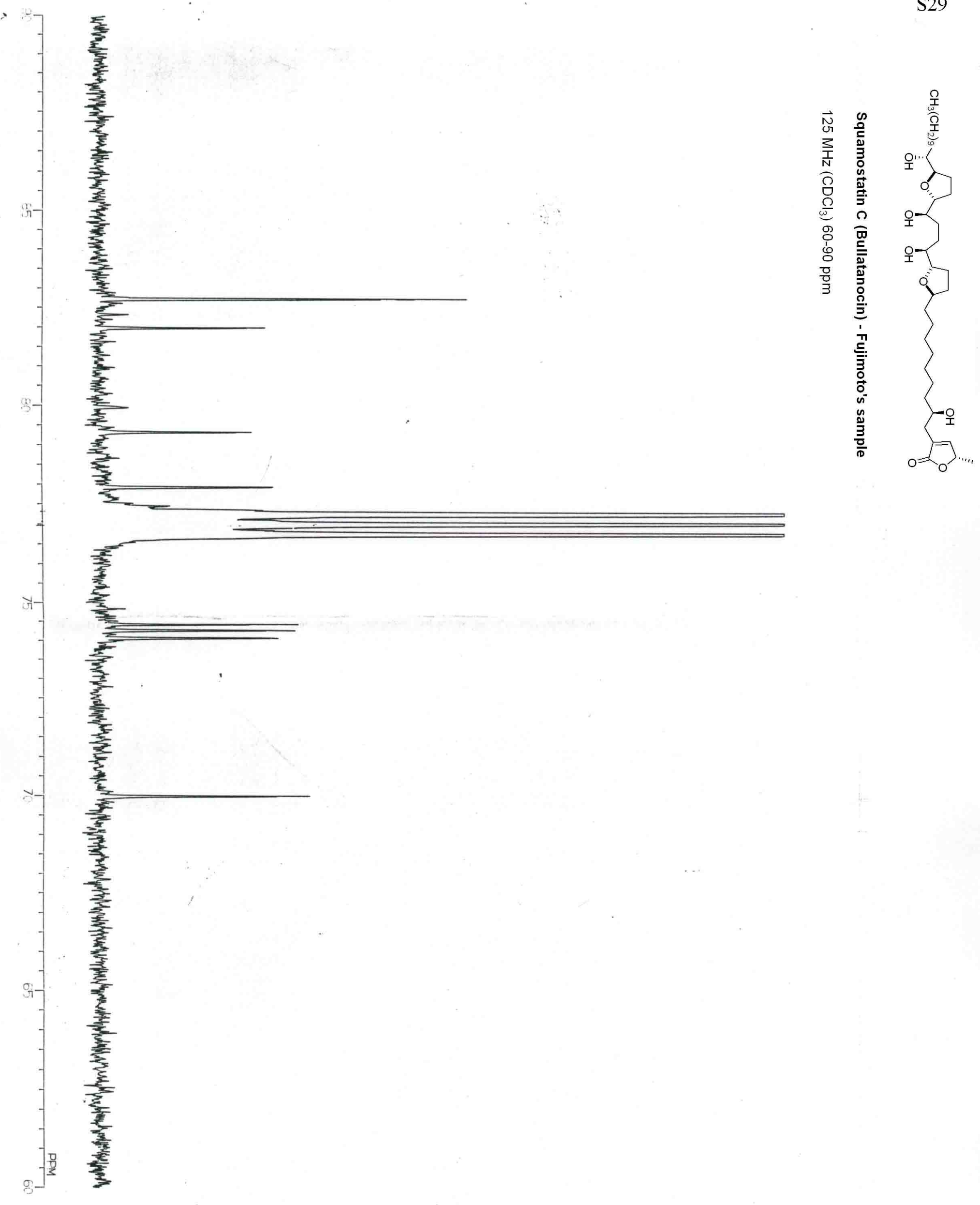


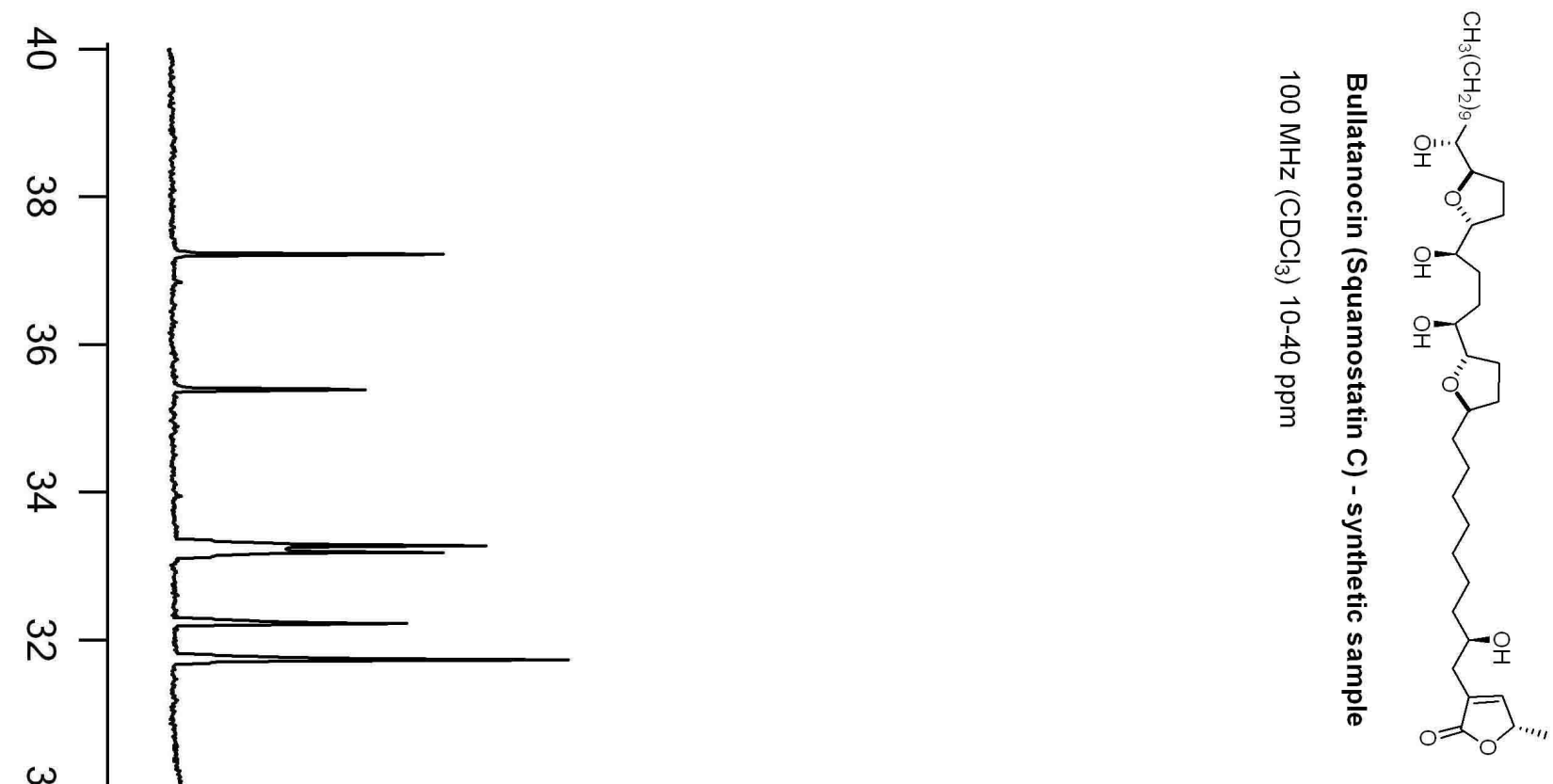


S31
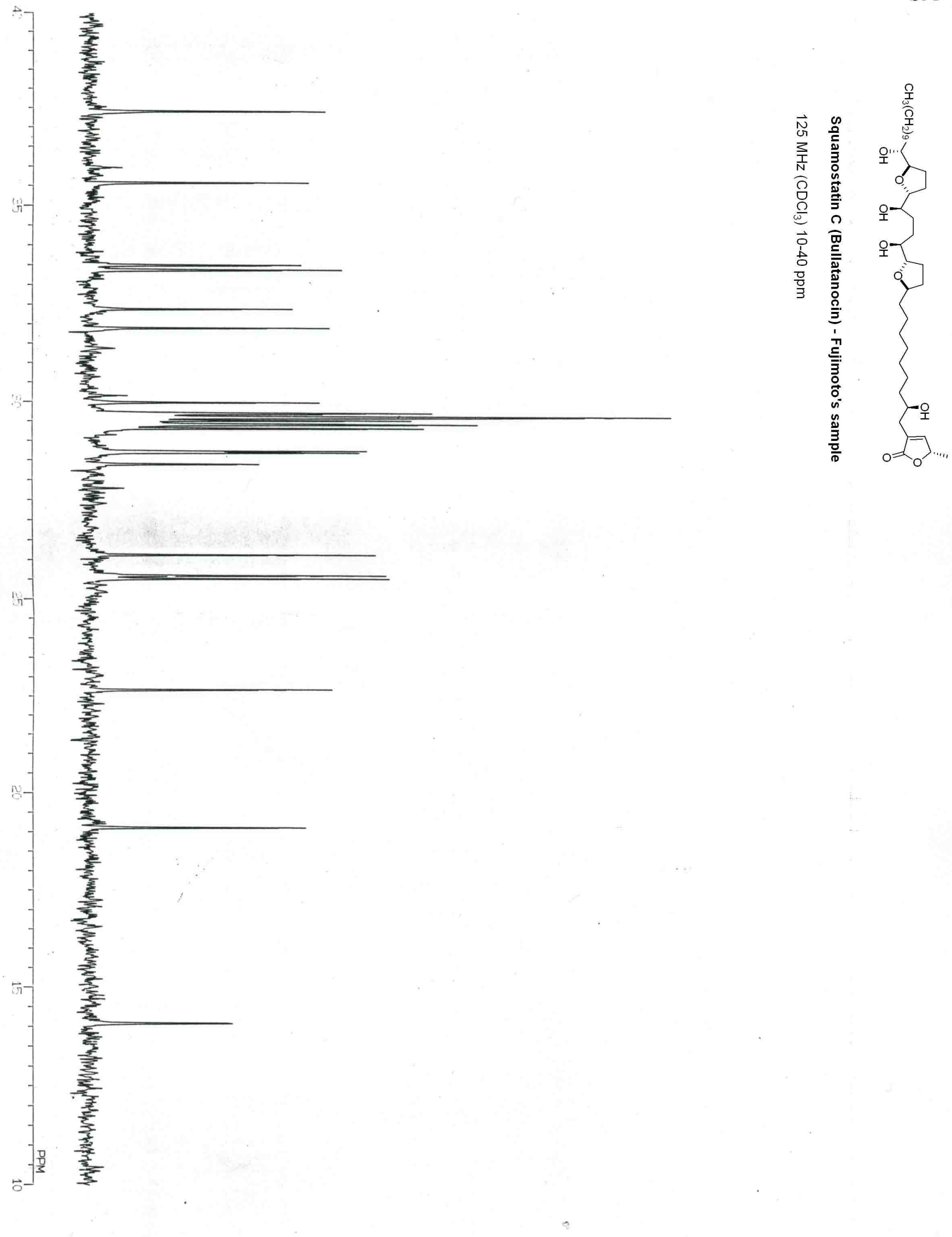


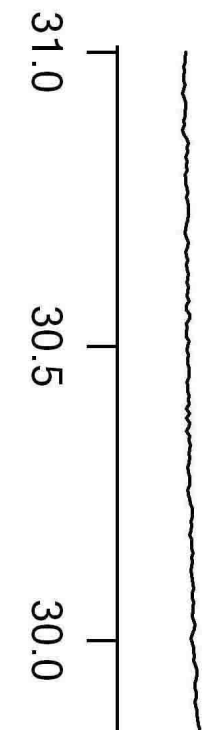

טே

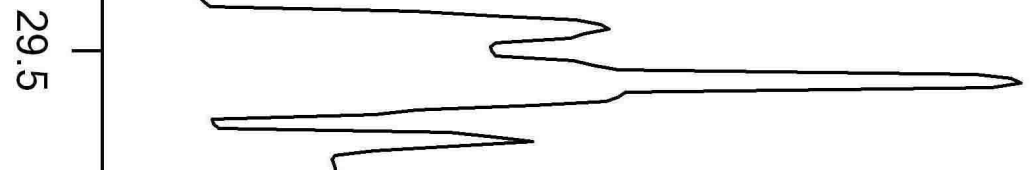

$\approx$

@

ur

○

N

0

r

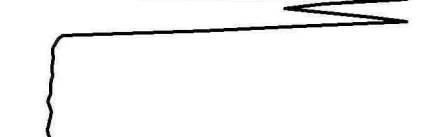

o 

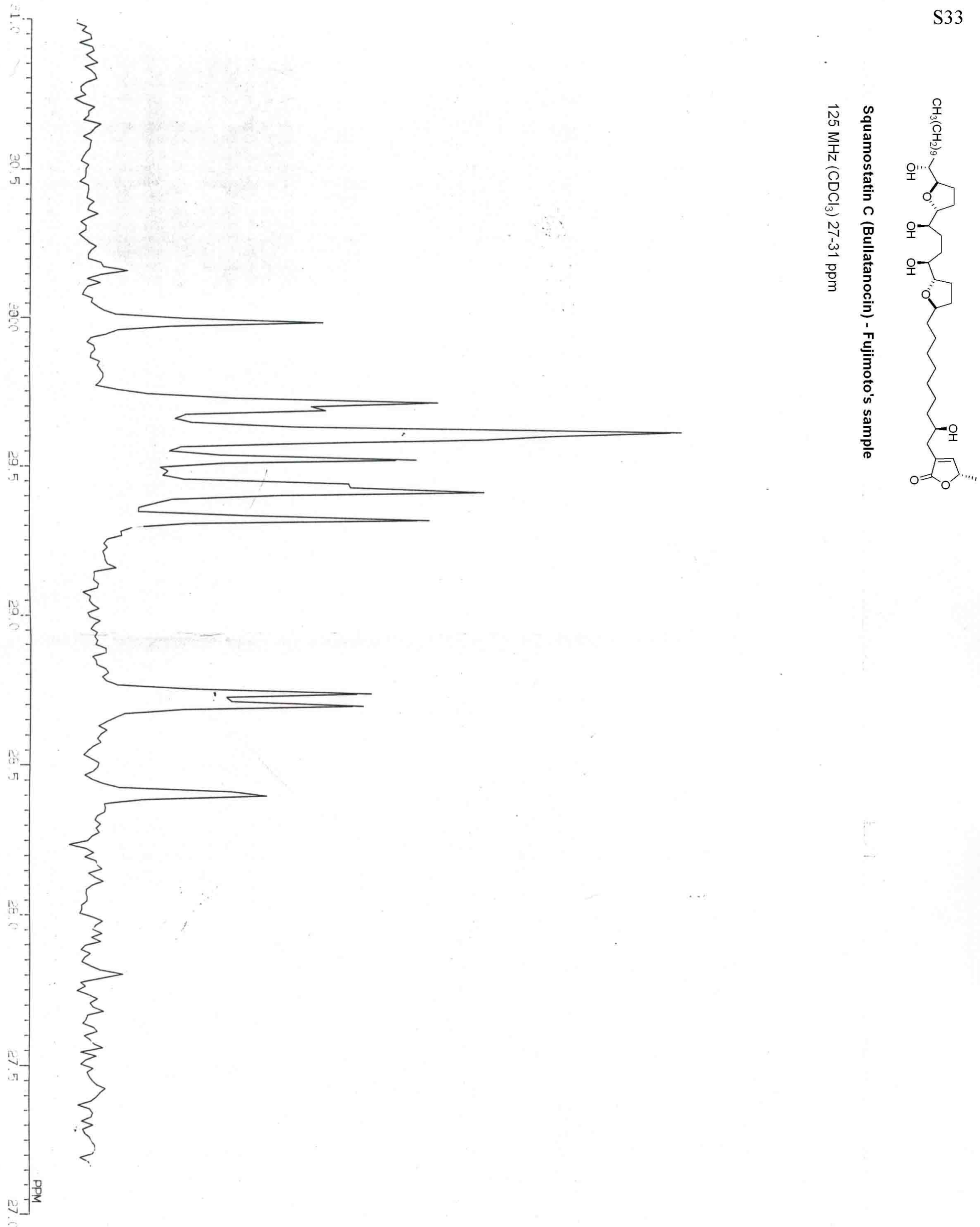